\title{
Changes in nutrient mass balances over time and related drivers for 54 New York State dairy farms
}

\author{
Melanie A. Soberon, Sebastian Cela, Quirine M. Ketterings, ${ }^{1}$ Caroline N. Rasmussen, and Karl J. Czymmek \\ Department of Animal Science, Cornell University, Ithaca, NY 14853
}

\begin{abstract}
Whole-farm nutrient mass balances (NMB) can assist producers in evaluation and monitoring the nutrient status of dairy farms over time. Most of the previous studies that report NMB for dairy farms were conducted over 1 to 3 yr. In this study, annual N, P, and K mass balances were assessed on 54 dairy farms in New York State for 4 to 6 yr between 2005 and 2010 with the objectives to (1) document changes in NMB over time and drivers for change, and (2) identify nutrient use efficiency parameters that predicted the potential for improvement in NMB. The study farms varied in size (42 small, 12 medium and large) and management practices. Phosphorus, $\mathrm{K}$, and $2 \mathrm{~N}$ balances (N1 without $\mathrm{N}_{2}$ fixation, and $\mathrm{N} 2$ including $\mathrm{N}_{2}$ fixation) were calculated. In general, farms with high initial NMB levels reduced them over time whereas farms with negative NMB tended to increase their NMB, demonstrating a tendency across all farms to move toward more optimal NMB levels over time. Sixty-three to $76 \%$ of farms (depending on the nutrient) reduced their NMB per hectare over the 4 to $6 \mathrm{yr}$, and 55 to $61 \%$ of these farms were able to do so while increasing milk production per cow. Across all farms, the overall reduction in NMB per hectare averaged $-22 \mathrm{~kg}$ of $\mathrm{N} / \mathrm{ha}$ for $\mathrm{N} 1$ (29\% reduction), $-16 \mathrm{~kg}$ of $\mathrm{N} / \mathrm{ha}$ for $\mathrm{N} 2(15 \%$ reduction), $-4 \mathrm{~kg}$ of $\mathrm{P} / \mathrm{ha}$ ( $36 \%$ reduction), and -10 $\mathrm{kg}$ of $\mathrm{K} / \mathrm{ha}$ ( $29 \%$ reduction). Change in feed imports was the most important driver for change in $\mathrm{N}$ and $\mathrm{P}$ balances across farms, whereas adjustments in both feed and fertilizer imports affected the K balances. Key predictors of potential areas for improvement in NMB over time include total nutrient imports, feed imports, animal density, percentage of farm-produced feed and nutrients, and feed nutrient use efficiency. Overall, this study highlights the opportunities of an adaptive management approach that includes NMB assessments to
\end{abstract}

Received December 13, 2014.

Accepted May 4, 2015.

${ }^{1}$ Corresponding author: qmk2@cornell.edu evaluate and monitor changes in nutrient use efficiency and cost-efficiency over time.

Key words: nitrogen, nutrient use efficiency, phosphorus, potassium, whole farm environmental assessment

\section{INTRODUCTION}

To become more economically and environmentally sustainable, dairy farmers need proactive management strategies that increase efficiency of nutrient use onfarm and reduce agriculture's environmental footprint. Currently, regulations in the United States are based on the development and implementation of a comprehensive nutrient management plan, but governmental agencies are exploring outcome-based approaches to encourage improvements in nutrient management over time (NRCS, 2013).

An adaptive management approach to whole-farm nutrient management can result in positive change over time as the producer first evaluates the effect of previous management changes through experimentation, data collection, and analyses, and then adjusts nutrient application strategies accordingly (Ketterings, 2013; NRCS, 2013). Various evaluation tools are available to evaluate field or animal performance; however, to evaluate performance at the whole-farm level, a wholefarm evaluation and monitoring tool is needed.

Nutrient mass balance (NMB) is one of few currently used on-farm tools in the United States that facilitate the adaptive management approach at the whole-farm level (Ketterings, 2013). One example is the Cornell University NMB calculator described in Soberon et al. (2013). An initial tier-1 NMB assessment allows a producer to assess how much $\mathrm{N}, \mathrm{P}$, and $\mathrm{K}$ is brought onto the farm via purchased feed, fertilizer, $\mathrm{N}_{2}$ fixation, purchased animals, or miscellaneous imports such as bedding, and to compare that to the amounts of $\mathrm{N}$, $\mathrm{P}$, and $\mathrm{K}$ exported from the farm in the form of milk, animals, crops, and manure. An NMB is generated for each nutrient $(\mathrm{N}, \mathrm{P}$, and $\mathrm{K})$ by subtracting the amount of each nutrient exported from the amount imported. The NMB value is expressed as NMB per hectare (an environmental impact indicator) and per megagram 
of milk production (a production efficiency indicator). The tier-2 assessment uses additional diagnostics to identify potential management areas for improvement (Soberon et al., 2013).

Extremely positive (imports $>$ exports) $\mathrm{N}$ balances are usually associated with low nutrient use efficiencies and high losses to the environment via runoff, leaching, denitrification, or volatilization (Kohn et al., 1997; Spears et al., 2003a,b). For P and K, extremely positive balances are associated with soil $\mathrm{P}$ and $\mathrm{K}$ buildup or losses via runoff and leaching, which may lead to water contamination. Negative (exports $>$ imports) $\mathrm{N}$ balances can negatively affect crop yields if $\mathrm{N}$ is not supplied by the soil. Negative P or K balances from fields with low fertility may indicate deficiencies in meeting crop requirements, and these deficiencies may increase over time. However, negative $\mathrm{P}$ and $\mathrm{K}$ balances could be justified in some systems if a farm has most of its fields with high soil test $\mathrm{P}$ and $\mathrm{K}$ levels because of previous over-applications (Gourley et al., 2012). In these situations, negative $\mathrm{P}$ and $\mathrm{K}$ balances could help minimize losses of $\mathrm{P}$ to water or excessive concentrations of $\mathrm{K}$ in forage. Over the long-term, slightly but not excessively positive NMB are required because of inefficiencies in crop and animal metabolisms. However, it should be recognized that slightly positive NMB do not necessarily imply that no nutrients are lost from the farm; nutrient allocation choices (fields, rate, timing, source, and method of application), as well as weather, drive actual environmental losses.

It is challenging to determine benchmark NMB values that will be both achievable and sustainable for dairy farms given certain climate and soil conditions (Nielsen and Kristensen, 2005). Though now abandoned due to overriding European Union-wide regulations, in the Netherlands, the Mineral Accounting System introduced in 1998, set nutrient per-hectare targets at the farm level for $\mathrm{N}$ and $\mathrm{P}$ (Oenema and Berentsen, 2005). The maximum allowed surpluses were, in 1998, set at $300 \mathrm{~kg}$ of $\mathrm{N} /$ ha for grassland, $175 \mathrm{~kg}$ of $\mathrm{N} / \mathrm{ha}$ for arable land, and $17.6 \mathrm{~kg}$ of $\mathrm{P} / \mathrm{ha}\left(40 \mathrm{~kg}\right.$ of $\left.\mathrm{P}_{2} \mathrm{O}_{5} / \mathrm{ha}\right)$, and gradually reduced to 140 to $180 \mathrm{~kg}$ of $\mathrm{N} / \mathrm{ha}$ for grassland, to 60 to $100 \mathrm{~kg}$ of N/ha for arable land, and to $8.8 \mathrm{~kg}$ of $\mathrm{P} / \mathrm{ha}\left(20 \mathrm{~kg}\right.$ of $\left.\mathrm{P}_{2} \mathrm{O}_{5} / \mathrm{ha}\right)$ in 2003 (Wright and Mallia, 2008). This approach did not consider $\mathrm{N}_{2}$ fixation as N input. In Belgium, Nevens et al. (2006) suggested benchmarks for $\mathrm{N}$ per hectare at $150 \mathrm{~kg}$ of $\mathrm{N} /$ ha, including $\mathrm{N}_{2}$ fixation as an input. Most recently, Cela et al. (2014) proposed $118 \mathrm{~kg}$ of $\mathrm{N} /$ ha (excluding $\mathrm{N}_{2}$ fixation), $146 \mathrm{~kg}$ of $\mathrm{N} / \mathrm{ha}$ (including $\mathrm{N}_{2}$ fixation), 13 $\mathrm{kg}$ of $\mathrm{P} / \mathrm{ha}$, and $41 \mathrm{~kg}$ of $\mathrm{K} / \mathrm{ha}$ as feasible benchmarks for New York, reflecting the lowest NMB that $75 \%$ of the farmers in the assessment were able to achieve.
Previous studies conducted in the United States suggested that key opportunities for dairy farms to reduce NMB relied upon better management of total imports, especially reducing feed imports, increasing the percentage of farm-produced feed, and increasing feed use efficiency (Kohn et al., 1997; Anderson and Magdoff, 2000; Erb and Fermanich, 2002; Spears et al., 2003a,b; Hristov et al., 2006). Most of the studies that evaluated changes in NMB over time were conducted in Europe (Swensson, 2003; Nielsen and Kristensen, 2005; Groot et al., 2006; Nevens et al., 2006), focused on N, and, in several of these studies, had limited number of farms or years included in the trend analysis.

With adaptive management strategies, the effects of specific management changes are best identified after multiple years of performance assessments. Given the potential for large year-to-year differences in weather, milk, feed, and fertilizer prices, a minimum of $4 \mathrm{yr}$ is needed to observe changes in nutrient balances due to implementation of management alternatives. Such longer-term records can be used to evaluate the main drivers for changes in NMB and to evaluate the performance of various nutrient use efficiency measurements (used in the tier 2 assessments) as indicators of possible management inefficiencies. The objectives of this study were (1) to document changes in NMB over time as well as the drivers for change in NMB using a set of 54 New York State (NY) dairy farms with at least $4 \mathrm{yr}$ of annual NMB, and (2) to identify the nutrient use efficiency parameters that predicted the potential for improvement.

\section{MATERIALS AND METHODS}

\section{Whole-Farm NMB}

Participating Dairies. The annual NMB assessment was conducted on $54 \mathrm{NY}$ dairy farms for 4 to 6 yr between 2005 and 2010, with 43, 51, 52, 52, 31, and 18 farms participating in 2005, 2006, 2007, 2008, 2009, and 2010, respectively. In the years for which the assessments were done, total annual rainfall in NY ranged from 1,011 to $1,165 \mathrm{~mm} / \mathrm{yr}$, whereas the average temperature ranged from 8.7 to $9.7^{\circ} \mathrm{C}$ (NYSASS, 2014). Years were slightly wetter and warmer than the normal (1970 to 2000) precipitation $(990 \mathrm{~mm}$ ) and normal temperature $\left(8.1^{\circ} \mathrm{C}\right)$ for $\mathrm{NY}$, but were comparable. Milk prices from 2005 to 2010 were $\$ 15.9,13.4,19.7$, $19.2,13.6$, and 17.4 per $45.4 \mathrm{~kg}$ of milk, and corn silage prices were $\$ 28.3,30.3,34.8,43.7,37.8$, and 39.7 per Mg (NYSASS, 2012) with the increases reflecting the biofuel (primarily ethanol) expansion locally and globally. 
The farms were located in 11 different NY watersheds, including the Allegheny River $(\mathrm{n}=1)$, Black River ( $\mathrm{n}$ $=1$ ), Chemung River $(\mathrm{n}=10)$, Delaware River ( $\mathrm{n}=$ $2)$, Genesee River $(\mathrm{n}=2)$, Lake Champlain $(\mathrm{n}=3)$, Lake Erie-Niagara River $(\mathrm{n}=1)$, Lake Ontario $(\mathrm{n}=1)$, Seneca-Oneida-Oswego Rivers $(\mathrm{n}=8)$, St. Lawrence River $(\mathrm{n}=6)$, and Susquehanna River watersheds ( $\mathrm{n}=$ 19). Herd sizes ranged from 25 to 1,813 milking cows. Forty-two farms were classified as small farms $(<200$ milk cows; USDA-EPA, 1999), 4 were medium farms (200 to 699 milk cows), and 8 were large farms ( $>700$ milk cows).

Data Collection. Farmers were invited to participate in NMB data collection by mail, extension presentations, or personal contacts by farm advisors or university staff. They were selected based upon willingness to participate and accessibility of adequate records to input the data needed for NMB assessment. We ensured the inclusion of small, medium, and large farms, although the 54-farm data set was skewed toward a higher percentage of medium and large farms compared with the statewide composition of dairy farm sizes in NY. Farm characteristics were recorded each year, including the total hectares on the farm, tillable hectares, hectares over which manure was spread, hectares in legume crops, milk cows, animal units (AU), milk production, and the amount of purchased versus farm-produced feed, grain, and forage. In addition, quantities and composition of purchased feed, fertilizer, animals, or bedding, and nutrient exports in the form of animals, milk, crops, and manure were documented. Animal units are defined as the sum of the number of animals for each animal group multiplied by the average BW in kilograms for each animal group and then divided by $454 \mathrm{~kg}$. Farms received annual NMB reports comparing their NMB with those of similar farms in NY but were not given benchmarks or advice on management changes. Detailed descriptions of the information recorded for the NMB assessment can be found in Soberon et al. (2013) and Cela et al. (2014).

Calculations. For each farm, NMB values were determined using the NMB calculator available from the Cornell University Nutrient Management Spear Program's website (http://nmsp.cals.cornell.edu), described in Soberon et al. (2013). Nutrient mass balances were formulated by summing the nutrients in imported feed, fertilizer, animals, and bedding, and subtracting exported nutrients in animals, crops, manure, and milk. The NMB were expressed as N, P, and K balances per tillable hectare (a gross measure of on-farm nutrient recycling) and per megagram of milk production (nutrient use efficiency indicator).
Atmospheric $\mathrm{N}$ deposition and $\mathrm{N}$ in irrigation water are $\mathrm{N}$ input sources that were not taken into consideration in the NMB calculations in our study, because atmospheric $\mathrm{N}$ deposition is not a factor farmers can manage and irrigation is used in only $0.17 \%$ of harvested cropland in NY (USDA-NASS, 2009). Nitrogen fixation by legume crops, an important $\mathrm{N}$ import, is typically the most uncertain value in an NMB assessment (Oenema et al., 2003; Gourley et al., 2012). Thus, $2 \mathrm{~N}$ balances are presented in our study: an $\mathrm{N}$ balance without consideration of $\mathrm{N}_{2}$ fixation (N1), and an $\mathrm{N}$ balance that includes a yield-specific $\mathrm{N}_{2}$ fixation estimate and assumes no manure is applied to legumes (N2). The N2 balance separates fields as $>90 \%$ legume (pure legume stands) versus $<90 \%$ legume. For $>90 \%$ legume stands, whole-farm $\mathrm{N}_{2}$ fixation is calculated as $0.6 \times$ hectares produced $\times \mathrm{DM}$ yield $\times$ average $\mathrm{CP}$ concentration/6.25. For each legume crop or pasture with $<90 \%$ legumes (60\% legume-grass mixture are more typical of $\mathrm{NY}$ fields), $\mathrm{N}_{2}$ fixation was estimated as $0.36 \times$ hectares produced $\times \mathrm{DM}$ yield $\times$ average $\mathrm{CP}$ concentration/6.25, as documented in Cela et al. (2014). Farmers keep good records of the main imports and exports pools (feed and fertilizer purchases, milk, animal, and crop sales), so the uncertainty in N1, P, and $\mathrm{K}$ balances is expected to be low. However, the uncertainty of $\mathrm{N} 2$ balances will be much larger because (1) $\mathrm{N}_{2}$ fixation is not directly measured by farmers; (2) most hay fields in NY dairies are mixtures of legumes and grass, and most farmers do not know the exact percentage of legumes in the mixtures; and (3) part of the legume acres receive manure, which reduces $\mathrm{N}_{2}$ fixation (Cela et al., 2014).

In addition to reporting of NMB per hectare and per milk production unit, several additional efficiency indicators were determined and reported to the participating farms.

(1) All feed $(\mathrm{kg}$ of DM) = purchased feed + farmproduced feed.

(2) Nutrients in all feed $(\mathrm{kg})=($ purchased feed $) \times$ (nutrient concentration) + (farm-produced feed $)$ $\times$ (nutrient concentration).

(3) Farm-produced feed ( $\mathrm{kg}$ of $\mathrm{DM})=$ farm crop production + initial inventory - final inventory - crops sold.

(4) Farm-produced feed nutrients $(\mathrm{kg})=[($ farm crop production $) \times($ nutrient concentration $)]+$ $[($ initial inventory - final inventory) $\times$ (nutrient concentration $)]-[($ crops sold $) \times($ nutrient concentration)]. 
(5) Farm-produced feed $(\%)=$ (farm-produced feed $/$ all feed) $\times 100$.

(6) Farm-produced feed nutrients (\%) = (farmproduced feed nutrients/nutrients in all feed) $\times$ 100.

(7) Feed nutrient use efficiency $(\%)=$ (total nutrients sold in milk + animals)/(all nutrients in feed).

(8) Whole-farm nutrient use efficiency $=$ (total nutrient exports/total nutrient imports $) \times 100$.

The percentage of homegrown feed and the feed nutrient use efficiency indicators are partly derived from homegrown crop information. Most dairy farmers in NY do not measure homegrown crop yields, so they provide estimates. Thus, a higher degree of uncertainty could be associated with the percentage of homegrown feed and the feed nutrient use efficiency estimates. Other efficiency indicators, such as apparent crop uptake and manure N availability (Kohn et al., 1997; Powell et al., 2010), could not be calculated; such data were not collected due to uncertainty, costs, and time involved in the assessments.

Initial and Final Assessments and Change Over Time. To account for weather-driven year-toyear differences, the first 2 and last 2 yr of data were averaged for each farm to obtain an initial NMB (T1) and a most current NMB assessment (T2). The change over time was determined as T2 - T1. The mean annual change in NMB was calculated by dividing the change over time by the number of years with NMB assessments.

\section{Statistical Analyses}

Descriptive statistics of farm characteristics, NMB, imports, and exports were calculated for the whole 54farm database at $\mathrm{T} 1$ and for the change over time (T2 T1). To identify main drivers of change in NMB, linear regression models were developed with change in NMB per hectare and per megagram of milk as the dependent variable and change in the different farm size and management indicators, and change in the different types of nutrient imports and managed exports as independent variables. Because change in feed import was the most important driver for a change in balance across farms, a stepwise regression (Proc Glmselect; SAS Institute Inc., 2012) was used to identify the farm characteristics and management practices that significantly $(P=$ $0.05)$ explained the changes in feed imports over time. Multivariate regression models (Proc Glm; SAS Institute Inc., 2012) were developed with the change in feed nutrient imports as the dependent variable, and the change in those farm characteristics and management practices that were significant in the stepwise regression as independent variables.

\section{RESULTS AND DISCUSSION}

\section{Initial Farm Size and Management Practices}

In the initial assessment (T1), the farm-size indicators varied widely among the study farms: 25 to 1,813 cows per herd, 36 to 1,199 tillable hectares, 0.41 to 3.95 $\mathrm{AU} / \mathrm{ha}, 1.5$ to $23.1 \mathrm{Mg}$ of milk produced/ha, 5.3 to 11.9 $\mathrm{Mg}$ of milk produced/cow per year, and 41 to $97 \%$ of homegrown feed in the rations (Table 1). Small farms had, on average, lower animal densities than medium and large farms (1.30 vs. $2.61 \mathrm{AU} /$ ha, respectively), lower milk production per cow ( 8.4 vs. $10.5 \mathrm{Mg} /$ cow per year, respectively), and a higher percentage of homegrown feed (77 vs. $68 \%$, respectively). The concentration of nutrients in all feed (homegrown crops - crop sold + change in inventories + purchased feed) ranged from 11.8 to $19.6 \% \mathrm{CP}, 0.24$ to $0.46 \% \mathrm{P}$, and 0.6 to $2.7 \% \mathrm{~K}$, whereas the concentration of nutrients in the purchased feed ranged from 9.5 to $40.0 \% \mathrm{CP}, 0.15$ to $1.20 \% \mathrm{P}$, and 0.7 to $2.2 \% \mathrm{~K}$ (Table 1 ). The initial feed nutrient use efficiencies across all farms averaged $17 \%$ for $\mathrm{N}, 22 \%$ for $\mathrm{P}$, and $8 \%$ for K. On average, feed use efficiencies were higher for medium and large farms $(22$, 28 , and 11 for $\mathrm{N}, \mathrm{P}$, and $\mathrm{K}$, respectively) than for small farms $(16,21$, and $7 \%$ for $\mathrm{N}, \mathrm{P}$, and $\mathrm{K}$, respectively).

\section{Initial Nutrient Imports and Exports}

In T1, total nutrient imports averaged $161 \mathrm{~kg}$ of $\mathrm{N} /$ ha (27 to $556 \mathrm{~kg}$ pf $\mathrm{N} / \mathrm{ha}$ ), $20 \mathrm{~kg}$ of $\mathrm{P} / \mathrm{ha}$ (2 to 65 $\mathrm{kg}$ of $\mathrm{P} / \mathrm{ha}$ ), and $54 \mathrm{~kg}$ of $\mathrm{K} / \mathrm{ha}$ (4 to $232 \mathrm{~kg}$ of K/ ha). Imported feed was the single largest contributor to nutrient imports, accounting, on average, for $100 \mathrm{~kg}$ of $\mathrm{N} / \mathrm{ha}, 15 \mathrm{~kg}$ of $\mathrm{P} / \mathrm{ha}$, and $36 \mathrm{~kg}$ of $\mathrm{K} / \mathrm{ha}(62,75$, and $67 \%$ of the total N2, P, and $\mathrm{K}$ imports, respectively; Figure 1). Fertilizer was the next largest contributor and averaged $29 \mathrm{~kg}$ of $\mathrm{N} / \mathrm{ha}, 5 \mathrm{~kg}$ of $\mathrm{P} / \mathrm{ha}$, and 17 $\mathrm{kg}$ of $\mathrm{K} / \mathrm{ha}(18,24$, and $31 \%$ of the total $\mathrm{N} 2, \mathrm{P}$, and $\mathrm{K}$ imports, respectively). Nitrogen fixation by legumes averaged $31 \mathrm{~kg}$ of N/ha (0 to $89 \mathrm{~kg}$ of N/ha) and accounted for $19 \%$ of the total N2 imports. On average, dairy farms in this study had $35 \%$ of the tillable land in legumes (Table 1), so total $\mathrm{N}_{2}$ fixation divided by the legume hectares averaged $92 \mathrm{~kg}$ of $\mathrm{N} / \mathrm{ha}$ and ranged from 18 to $211 \mathrm{~kg}$ of $\mathrm{N} / \mathrm{ha}$. The $\mathrm{N}_{2}$ fixation estimates considered in our study fall within the range of $\mathrm{N}_{2}$ fixed by legumes in pasture summarized by Rotz et al. (2005; 10 to $270 \mathrm{~kg}$ of N/ha, with most estimates between 100 and $200 \mathrm{~kg}$ of $\mathrm{N} / \mathrm{ha}$ ) and are similar to those reported in other NMB studies: $17 \mathrm{~kg}$ of N/ha (0 to $289 \mathrm{~kg}$ of N/ 


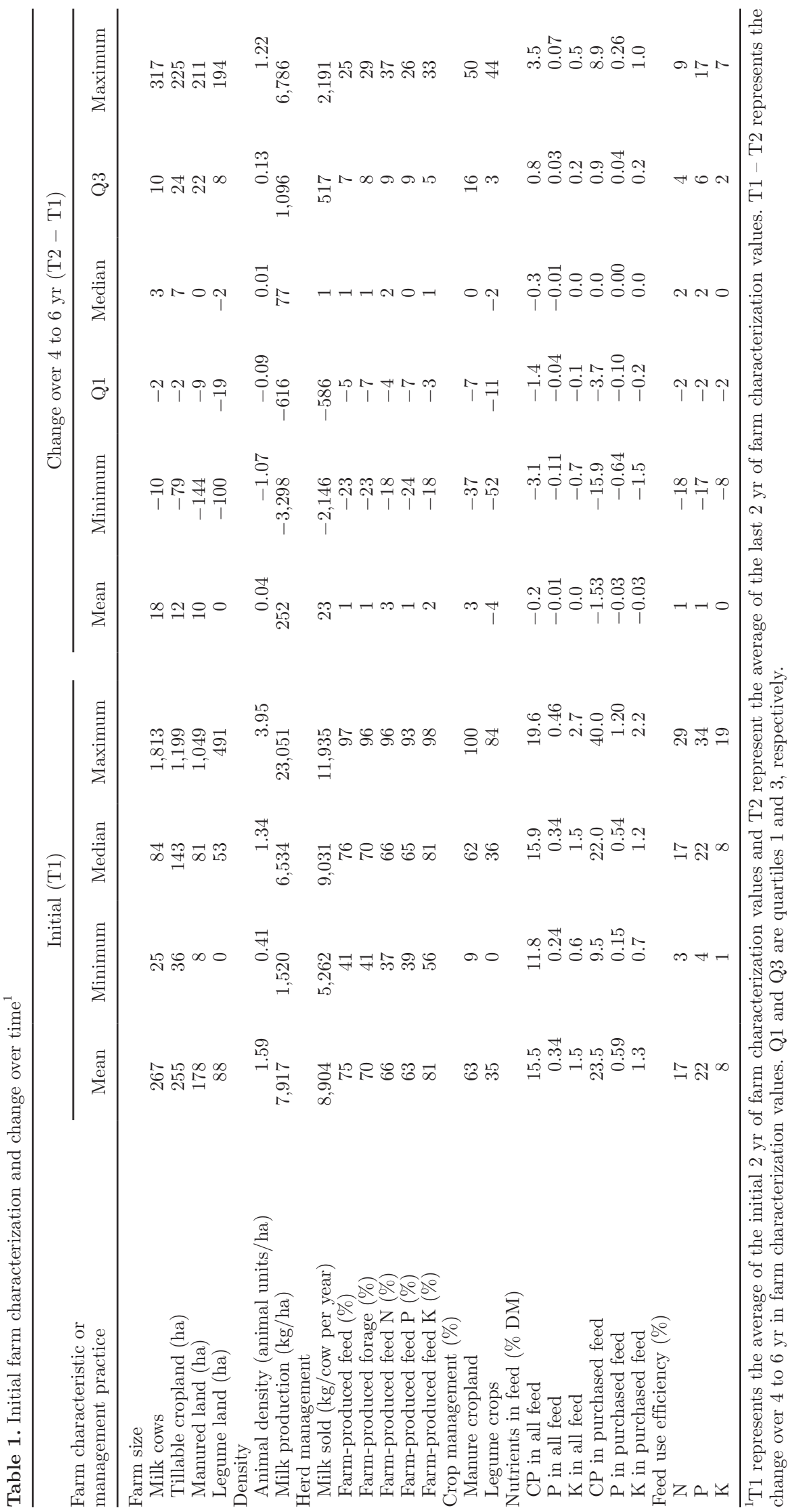



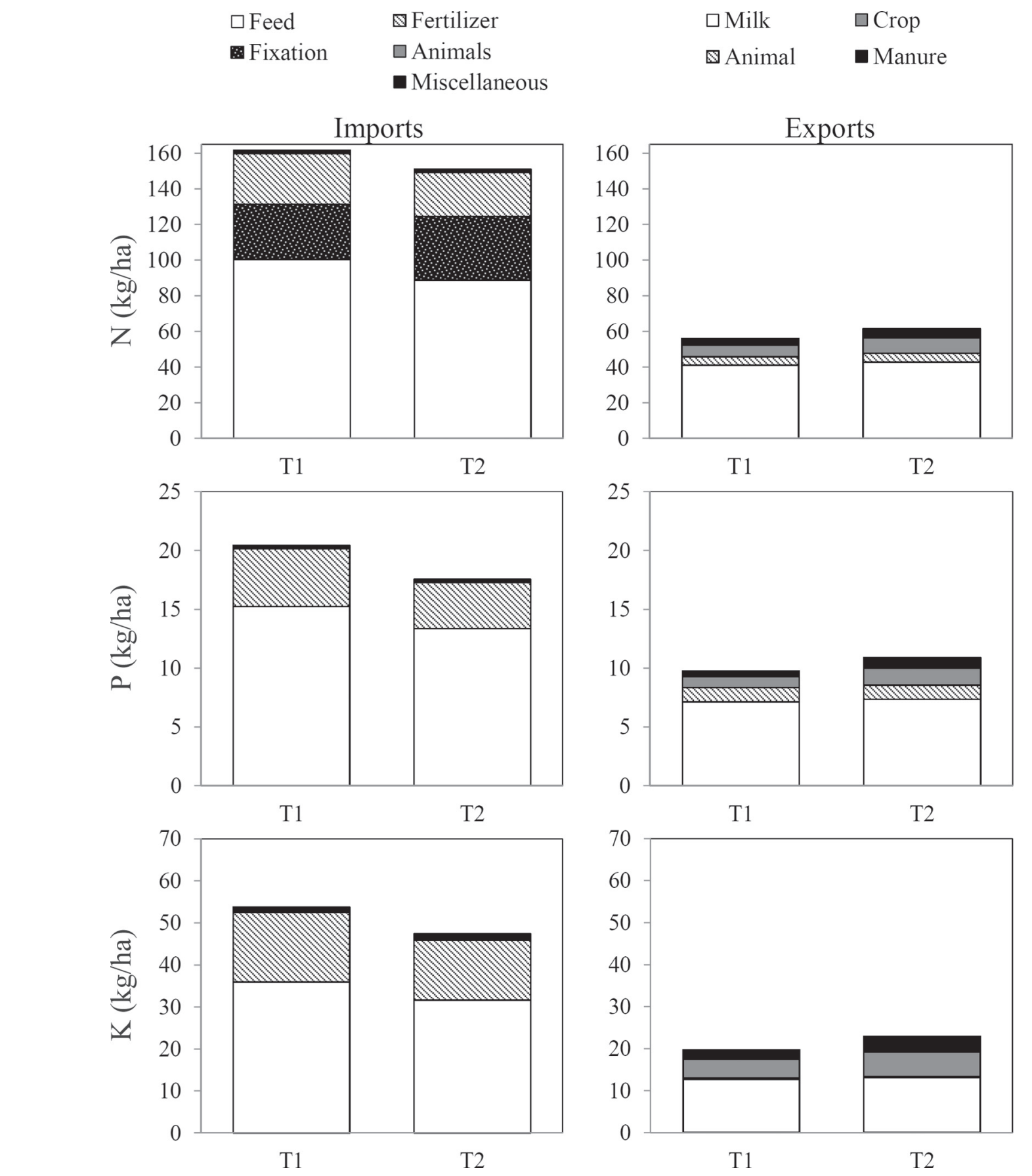

Figure 1. Average amount of N, P, and K imported onto and exported from 54 dairy farms in New York State in the beginning (T1) and the end (T2) of the study period, for the different types of imports and exports.

ha; Gourley et al., 2012), $27 \pm 19 \mathrm{~kg}$ of $\mathrm{N} / \mathrm{ha}$ (Nielsen and Kristensen, 2005), $33 \pm 21 \mathrm{~kg}$ of N/ha (Swensson, 2003), $60 \mathrm{~kg}$ of $\mathrm{N} /$ ha for grass and clover mixtures (Nevens et al., 2006).

In $\mathrm{T} 1$, total exports averaged $56 \mathrm{~kg}$ of $\mathrm{N} / \mathrm{ha}$ (13 to $236 \mathrm{~kg}$ of $\mathrm{N} / \mathrm{ha}$ ), $10 \mathrm{~kg}$ of $\mathrm{P} / \mathrm{ha}$ (2 to $34 \mathrm{~kg}$ of $\mathrm{P} /$ ha), and $20 \mathrm{~kg}$ of $\mathrm{K} / \mathrm{ha}$ (5 to $106 \mathrm{~kg}$ of $\mathrm{K} / \mathrm{ha}$ ). Milk export was the biggest contributor to nutrient exports, accounting on average for 73,73 , and $64 \%$ of the total N, P, and K exports (Figure 1). Animals, crops and manure accounted, on average, for 9 to 13, 11 to 12, and 2 to $3 \%$ of the total $\mathrm{N}$ and $\mathrm{P}$ exports, and 2, 18, and 
Table 2. Initial balance characterization and change over time ${ }^{1}$

\begin{tabular}{|c|c|c|c|c|c|c|c|c|c|c|}
\hline Nutrient $^{2}$ & \multicolumn{4}{|c|}{ Initial (T1) } & \multicolumn{6}{|c|}{ Change over 4 to 6 yr $(\mathrm{T} 2-\mathrm{T} 1)$} \\
\hline \multicolumn{11}{|c|}{ Balance (kg/ha) } \\
\hline $\mathrm{N} 2$ & 106 & -11 & 93 & 319 & -16 & -141 & -33 & -9 & 10 & 77 \\
\hline $\mathrm{P}$ & 11 & -9 & 9 & 47 & -4 & -26 & -6 & -3 & 0 & 10 \\
\hline K & 34 & -44 & 28 & 204 & -10 & -73 & -15 & -6 & 2 & 91 \\
\hline \multicolumn{11}{|c|}{ Balance $(\mathrm{kg} / \mathrm{Mg}$ of milk) } \\
\hline $\mathrm{P}$ & 1.3 & -1.4 & 1.3 & 3.2 & -0.5 & -2.6 & -0.8 & -0.5 & -0.1 & 1.6 \\
\hline K & 3.6 & -18.1 & 3.5 & 13.9 & -1.3 & -10.0 & -2.6 & -0.8 & 0.3 & 7.8 \\
\hline
\end{tabular}

${ }^{1}$ T1 represents the average nutrient mass balance for the first $2 \mathrm{yr}$ of data collection; T2 represent the average nutrient mass balance values for the final $2 \mathrm{yr}$ of data collection; T1 - T2 represents the change over 4 to 6 years in farm nutrient mass balance. Q1 and Q3 are quartiles 1 and 3 , respectively.

${ }^{2} \mathrm{~N} 1$ represents $\mathrm{N}$ mass balance without considering $\mathrm{N}_{2}$ fixation, $\mathrm{N} 2$ represents an $\mathrm{N}$ balance that includes a yield-specific $\mathrm{N}_{2}$ fixation and assumes no manure is applied to legumes.

$4 \%$ of the total $\mathrm{K}$ exports, respectively. These findings are similar to those reported in previous studies conducted in the northeast United States (Anderson and Magdoff, 2000), in the western United States (Spears et al., 2003a, b; Hristov et al., 2006), and in some European dairies (Nielsen and Kristensen, 2005; Fangueiro et al., 2008). However, nutrient imports via fertilizer were larger than imports via feed in some European and Australian dairy farms (Swensson, 2003; Groot et al., 2006; Nevens et al., 2006; Gourley et al., 2012).

\section{Initial NMB per Hectare and per Megagram of Milk Produced}

In the first $2 \mathrm{yr}$ of the study, NMB per hectare varied widely across the 54 dairy farms, averaging 75 and 106 $\mathrm{kg}$ of $\mathrm{N} / \mathrm{ha}$ for $\mathrm{N} 1$ and $\mathrm{N} 2$, respectively, $11 \mathrm{~kg}$ of $\mathrm{P} /$ ha, and $34 \mathrm{~kg}$ of $\mathrm{K} /$ ha (Table 2). In T1, 7 farms had negative $\mathrm{N} 1$ balances, 2 farms had small negative N2 balances $(-11$ and $-1 \mathrm{~kg}$ of $\mathrm{N} / \mathrm{ha})$, whereas 2 and 4 farms had negative $\mathrm{P}$ and $\mathrm{K}$ balances, respectively. The average NMB per hectare were higher for medium and large farms $(150,188,17$, and $58 \mathrm{~kg} /$ ha for $\mathrm{N} 1, \mathrm{~N} 2, \mathrm{P}$, and $\mathrm{K}$, respectively) than for small farms $(54,82,9$, and $27 \mathrm{~kg} / \mathrm{ha}$ for $\mathrm{N} 1, \mathrm{~N} 2, \mathrm{P}$, and $\mathrm{K}$, respectively), consistent with the higher animal density of the medium and large farms.

Similarly, balances per megagram of milk produced in $\mathrm{T} 1$ also varied largely across the 54 farms, averaging 8.1 and $12.9 \mathrm{~kg}$ of $\mathrm{N} / \mathrm{Mg}$ for $\mathrm{N} 1$ and $\mathrm{N} 2$, respectively, 1.3 $\mathrm{kg}$ of $\mathrm{P} / \mathrm{Mg}$, and $3.6 \mathrm{~kg}$ of $\mathrm{K} / \mathrm{Mg}$ (Table 2 ). The average $\mathrm{N} 1$ and $\mathrm{K}$ balances per megagram of milk produced were lower for small farms compared with medium and large farms ( 7.4 vs. $10.5 \mathrm{~kg}$ of N/Mg and 3.5 vs. $4.2 \mathrm{~kg}$ of $\mathrm{K} / \mathrm{Mg}$, respectively), whereas the average $\mathrm{N} 2$ and $\mathrm{P}$ balances per megagram of milk produced were similar among farm sizes (12.8 and $13.2 \mathrm{~kg}$ of $\mathrm{N} / \mathrm{Mg}$ for N2, and 1.4 and $1.2 \mathrm{~kg}$ of $\mathrm{P} / \mathrm{Mg}$ for small farms vs. medium and large farms, respectively).

The small negative N2 balances may be partially accounted for by atmospheric $\mathrm{N}$ deposition (not included in our assessment) and by uncertainty associated with $\mathrm{N}_{2}$ fixation estimates. In general, the NMB reported in our study fall within the very large range of NMB reported for dairy farms in previous studies: 15 to 748 $\mathrm{kg}$ of $\mathrm{N} / \mathrm{ha},-7$ to $133 \mathrm{~kg}$ of $\mathrm{P} / \mathrm{ha}$, and 2 to $452 \mathrm{~kg}$ of $\mathrm{K} / \mathrm{ha}$; and 9.0 to $45 \mathrm{~kg}$ of N/Mg, -0.6 to $17 \mathrm{~kg}$ of $\mathrm{P} /$ $\mathrm{Mg}$, and 0.0 to $25 \mathrm{~kg}$ of $\mathrm{K} / \mathrm{Mg}$ (Swensson, 2003; Nielsen and Kristensen, 2005; Hristov et al., 2006; Gourley et al., 2007, 2012; Fangueiro et al., 2008). However, the highest NMB reported in our NY study were much lower than the highest NMB reported in those previous studies. This trend may be explained by the relatively low animal densities of some NY dairies (Table 1) and by the relatively low fertilizer inputs in NY dairies compared with some of their counterparts in Europe or Australia. This trend is also consistent with the low (or negative) statewide crop $\mathrm{N}$ balances reported for $\mathrm{NY}$ (Swink et al., 2011).

In $\mathrm{T} 1$, the whole-farm nutrient use efficiencies varied widely, from 23 to $413 \%$ for N1 (median $=43 \%$ ), from 24 to $224 \%$ for N2 (median $=35 \%$ ), from 10 to $343 \%$ for $\mathrm{P}$ (median $=47 \%$ ), and from 19 to $110 \%$ for $\mathrm{K}$ (median $=38 \%$ ). Compared with medium and large farms, small farms had higher median whole-farm use efficiencies for N1 (45 vs. 41\%) and for K (39 vs. $33 \%)$, similar efficiencies for $\mathrm{N} 2(35-36 \%)$, and lower efficiencies for P (46 vs. $54 \%$ ). The whole-farm nutrient use efficiencies reported in our study were similar to or higher than ranges reported in previous studies: 8 to 
$64 \%$ for N (Powell et al., 2010), 6 to $158 \%$ for P, and 9 to $157 \%$ for K (Spears et al., 2003a,b; Hristov et al., 2006; Gourley et al., 2012).

\section{Change Over Time in NMB}

NMB per Hectare. The N1 balance averaged $75 \mathrm{~kg}$ of $\mathrm{N} / \mathrm{ha}$ at the start of the assessments, and decreased to $53 \mathrm{~kg}$ of $\mathrm{N} /$ ha over 4 to $6 \mathrm{yr}$ (29\% reduction). This represents a mean change in N1 balance of $-22 \mathrm{~kg}$ of $\mathrm{N} /$ ha (or $-4.6 \mathrm{~kg}$ of $\mathrm{N} /$ ha per year; Table 2), with a range from -140 to $+66 \mathrm{~kg}$ of $\mathrm{N} / \mathrm{ha}(-35$ to +17 $\mathrm{kg}$ of $\mathrm{N} /$ ha per year). The $\mathrm{N}$ balance with $\mathrm{N}$ fixation (N2) averaged $106 \mathrm{~kg} / \mathrm{ha}$ initially and decreased to 90 $\mathrm{kg}$ of $\mathrm{N} /$ ha over time ( $15 \%$ reduction; Table 2$)$. This represents a mean change in $\mathrm{N} 2$ balance of $-16 \mathrm{~kg}$ of $\mathrm{N} / \mathrm{ha}$ (or $-3.3 \mathrm{~kg}$ of $\mathrm{N} / \mathrm{ha}$ per year), with a range of -141 to $+77 \mathrm{~kg}$ of $\mathrm{N} / \mathrm{ha}(-35$ to $+19 \mathrm{~kg}$ of $\mathrm{N} / \mathrm{ha}$ per year). The initial average $\mathrm{P}$ balance decreased from 11 $\mathrm{kg}$ of $\mathrm{P} / \mathrm{ha}$ in the first $2 \mathrm{yr}$ to $7 \mathrm{~kg}$ of $\mathrm{P} /$ ha in the last 2 yr (36\% reduction). This corresponds to a mean change in $\mathrm{P}$ balance of $-4 \mathrm{~kg}$ of $\mathrm{P} / \mathrm{ha}(-0.9 \mathrm{~kg}$ of $\mathrm{P} / \mathrm{ha}$ per year; Table 2), with a range from -26 to $+10 \mathrm{~kg}$ of $\mathrm{P} /$ ha $(-5.5$ to $+2.5 \mathrm{~kg}$ of $\mathrm{P} /$ ha per year). Similarly, the initial $\mathrm{K}$ balance decreased from $34 \mathrm{~kg}$ of $\mathrm{K} / \mathrm{ha}$ to 24 $\mathrm{kg}$ of $\mathrm{K} / \mathrm{ha}$ ( $29 \%$ reduction), with a range in $\mathrm{K}$ balance change of -73 to $+91 \mathrm{~kg}$ of $\mathrm{K} / \mathrm{ha}(-16$ to $+18 \mathrm{~kg}$ of $\mathrm{K} /$ ha per year) over the 4 to $6 \mathrm{yr}$ (Table 2).

Farms with the highest NMB in T1 exhibited the most drastic reductions in NMB over time, whereas farms that had low or negative balances in T1 tended to increase their balances over time (Figure 2). Thus, the results suggest that the farms made changes in NMB that were directionally correct, a trend that is still evident even if a large degree of uncertainty was assumed for each NMB.

Overall, 74, 63, 76, and $63 \%$ of the farms in our study reduced their $\mathrm{N} 1, \mathrm{~N} 2, \mathrm{P}$, and $\mathrm{K}$ mass balances per hectare over the 4 to 6 yr (Figure 2). A similar percentage of small versus medium and large farms reduced $\mathrm{N}$ balances over time ( 74 to $75 \%$ for N1 and 62 to $67 \%$ for $\mathrm{N} 2$ ), but a larger percentage of medium and large farms reduced $\mathrm{P}$ and $\mathrm{K}$ balances over time $(92 \%$ for $\mathrm{P}$ and $75 \%$ for K) compared with small farms ( $71 \%$ for $\mathrm{P}$ and $60 \%$ for $\mathrm{K})$.

Initially in T1, 36 of the 42 small farms (86\%) and 5 of 12 medium and large farms (42\%) operated with $\mathrm{N}$ balances per hectare below the feasible benchmarks proposed for NY dairies by Cela et al. (2014; Table $3)$. By T2, the percentages of small versus medium and large farms producing milk with $\mathrm{N}$ balances per hectare below the feasible benchmark had increased to 93 and 50\%, respectively (Table 3). The largest reduction in $\mathrm{P}$ and $\mathrm{K}$ balances per hectare occurred in the medium and large farms (Table 3 ). The percentage of medium and large farms operating with $\mathrm{P}$ and $\mathrm{K}$ balances per hectare below the benchmark increased from 42 and $25 \%$ in $\mathrm{T} 1$, respectively, to 75 and $50 \%$ in $\mathrm{T} 2$, respectively (Table 3 ). Of the farms that reduced their NMB over time, 55 to $61 \%$ (depending on the nutrient) were able to do so while increasing milk production per cow over time (Figure 3). These farms illustrated that reductions in NMB per hectare over time are not made at the expense of milk production per cow.

Similar reductions in $\mathrm{N}$ balances per hectare were reported in Europe. Swensson (2003) reported that N surpluses in 138 dairy farms in Sweden decreased 25 $\mathrm{kg}$ of $\mathrm{N} /$ ha over $3 \mathrm{yr}$ (on average, $-8.3 \mathrm{~kg}$ of $\mathrm{N} / \mathrm{ha}$ per year), whereas $\mathrm{P}$ and $\mathrm{K}$ surpluses did not change over time. Nielsen and Kristensen (2005) demonstrated that $\mathrm{N}$ surpluses in 8 conventional dairy farms in Denmark decreased from 190 to $155 \mathrm{~kg}$ of $\mathrm{N} /$ ha over $6 \mathrm{yr}$ (on average, $-5.8 \mathrm{~kg}$ of $\mathrm{N} /$ ha per year), whereas $\mathrm{N}$ surplus in 5 organic dairy farms decreased from 111 to $87 \mathrm{~kg}$ of $\mathrm{N} /$ ha over $4 \mathrm{yr}$ (on average, $-6 \mathrm{~kg}$ of $\mathrm{N} /$ ha per year). Nevens et al. (2006) reported that N surpluses in Flemish dairy farms decreased from $378 \mathrm{~kg}$ of $\mathrm{N} / \mathrm{ha}$ in 1989 to $238 \mathrm{~kg}$ of N/ha in 2001 (on average, $-10.8 \mathrm{~kg}$ of N/ ha per year). Fangueiro et al. (2008) reported reductions in NMB per hectare over 3 yr of $-139 \mathrm{~kg}$ of $\mathrm{N} /$ ha $(-46 \mathrm{~kg}$ of $\mathrm{N} / \mathrm{ha}$ per year $),-36 \mathrm{~kg}$ of $\mathrm{P} / \mathrm{ha}(-12$ $\mathrm{kg}$ of $\mathrm{P} / \mathrm{ha}$ per year), and $-110 \mathrm{~kg}$ of $\mathrm{K} / \mathrm{ha}(-37 \mathrm{~kg}$ of $\mathrm{K} /$ ha per year) in very intensively managed dairy farms in Portugal. These studies suggest that farms that monitor the NMB over time tend to make changes that improve whole-farm nutrient use efficiency.

NMB per Megagram of Milk Produced. The change over the 4 to $6 \mathrm{yr}$ in NMB per megagram of milk also varied widely among farms (Table 2). On average, NMB per megagram of milk decreased from 8.1 to $5.2 \mathrm{~kg}$ of $\mathrm{N} / \mathrm{Mg}$ for $\mathrm{N} 1$ (36\% reduction), from 12.9 to $11.9 \mathrm{~kg}$ of $\mathrm{N} / \mathrm{Mg}$ for $\mathrm{N} 2$ (7\% reduction), from 1.4 to $0.9 \mathrm{~kg}$ of $\mathrm{P} / \mathrm{Mg}$ ( $35 \%$ reduction), and from 3.7 to 2.4 $\mathrm{kg}$ of $\mathrm{K} / \mathrm{Mg}$ (35\% reduction). The average reductions over the 4 to 6 yr in $\mathrm{N}$ and $\mathrm{P}$ balances per megagram of milk were higher for medium and large farms $(-3.8$ $\mathrm{kg} / \mathrm{Mg}$ for $\mathrm{N} 1,-3.3 \mathrm{~kg} / \mathrm{Mg}$ for $\mathrm{N} 2$, and $-0.6 \mathrm{~kg} / \mathrm{Mg}$ for P) than for small farms $(-2.7 \mathrm{~kg} / \mathrm{Mg}$ for N1, $-0.3 \mathrm{~kg} /$ $\mathrm{Mg}$ for $\mathrm{N} 2$, and $-0.4 \mathrm{~kg} / \mathrm{Mg}$ for $\mathrm{P}$ ). For $\mathrm{K}$, the average reductions over the 4 to $6 \mathrm{yr}$ in NMB per megagram of milk were similar between the farm sizes $(-1.3 \mathrm{~kg} / \mathrm{Mg}$; Table 2). Across all 54 farms, the number of farms that met the feasible benchmarks for NMB per megagram of milk produced (based on Cela et al., 2014) increased between $\mathrm{T} 1$ and $\mathrm{T} 2$ from 26 to 40 for N1, from 24 to 35 for N2, from 21 to 35 for $\mathrm{P}$, and from 23 to 33 for $\mathrm{K}$ (Table 3), showing large improvements made by the farms. Over the same time span, milk production 

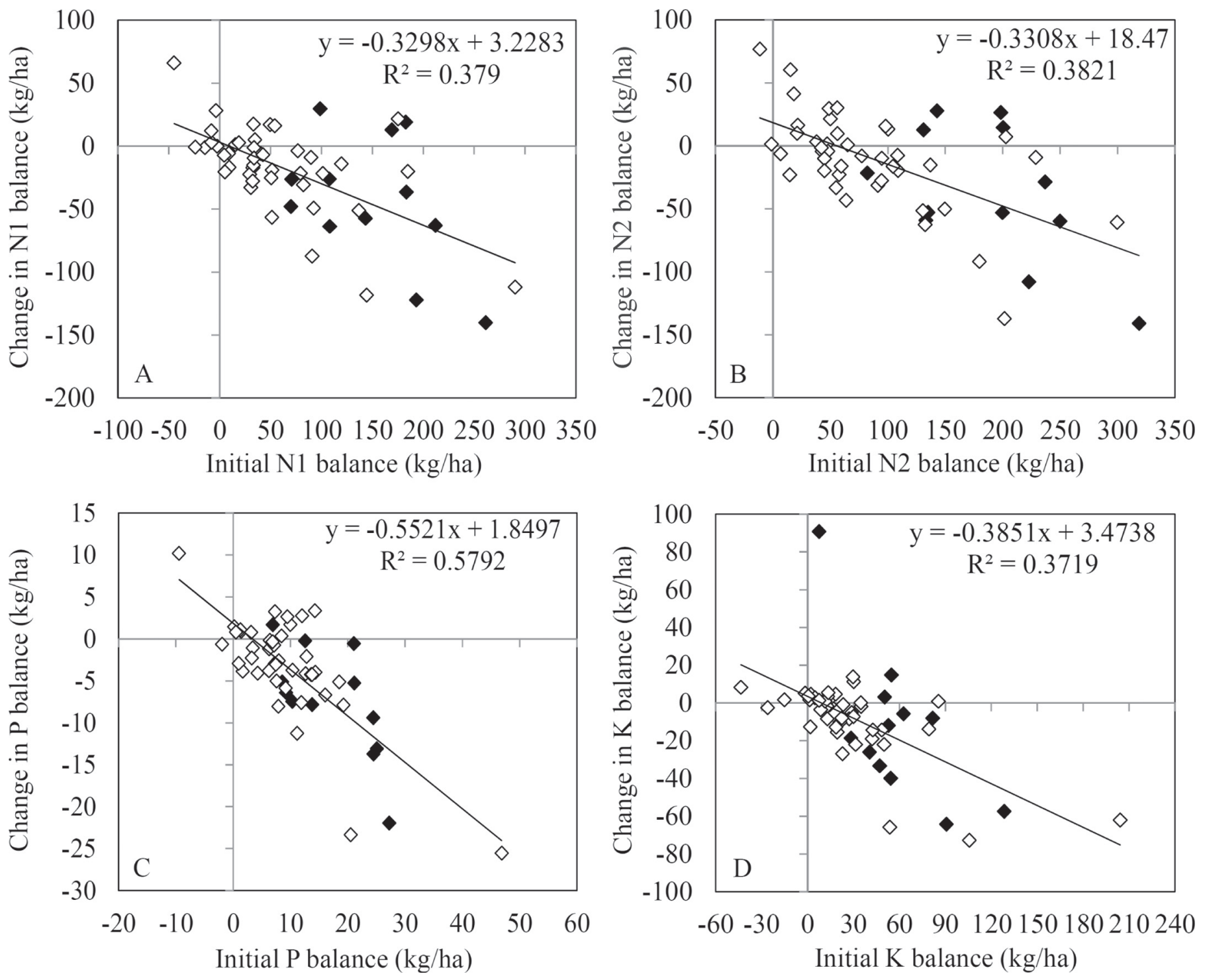

Figure 2. Change over 4 to 6 yr (T2 - T1) in nutrient mass balances for (A) nitrogen with $\mathrm{N}_{2}$ fixation (N1), (B) nitrogen without $\mathrm{N}_{2}$ fixation (N2), (C) phosphorus, and (D) potassium as a function of the initial nutrient mass balances for 54 dairy farms in New York State. Closed diamonds $(\bullet)$ represent medium and large farms $(>200$ cows), whereas open diamonds $(\diamond)$ represent small farms $(<200$ cows).

across all farms increased from 7,917 to $8,169 \mathrm{~kg} / \mathrm{ha}$, with similar milk production per cow in $\mathrm{T} 1(8,904 \mathrm{~kg} /$ cow per year) and in T2 $(8,927 \mathrm{~kg} /$ cow per year; Table 1). In comparison, Nevens et al. (2006) reported that the range of $\mathrm{N}$ surpluses per megagram of milk within which $90 \%$ of the Flemish study farms were operating decreased from 25 to $67 \mathrm{~kg}$ of $\mathrm{N} / \mathrm{Mg}$ in 1989 to 1990 to 17 to $50 \mathrm{~kg}$ of $\mathrm{N} / \mathrm{Mg}$ in 2000 to 2001 . Fangueiro et al. (2008) reported reductions in NMB per megagram of milk over $3 \mathrm{yr}$ in very intensive Portuguese dairy farms from 18 to $12 \mathrm{~kg}$ of $\mathrm{N} / \mathrm{Mg}$, from 1.8 to $0.9 \mathrm{~kg}$ of $\mathrm{P} / \mathrm{Mg}$, and from 5.0 to $1.7 \mathrm{~kg}$ of $\mathrm{K} / \mathrm{Mg}$. As previously mentioned, these results indicate that improvements in balances can be made without a negative effect on milk production (Figure 3).

The median whole-farm nutrient use efficiency of the $54 \mathrm{NY}$ dairies increased over time, from 43 to $54 \%$ for $\mathrm{N} 1$, from 35 to $39 \%$ for N2, from 47 to $57 \%$ for $\mathrm{P}$, and from 38 to $47 \%$ for $\mathrm{K}$. Of the 54 farms, 78, 67, 76, and $72 \%$ improved the whole-farm N1, N2, P, and K use efficiencies over time, respectively. For N2, the increases in whole-farm use efficiency over time were similar between farm sizes. For P and K, medium and large farms had larger increases in whole-farm use efficiency over time ( $16 \%$ for P, $19 \%$ for $\mathrm{K})$ than small farms $(7 \%$ for $\mathrm{P}, 6 \%$ for $\mathrm{K})$. 
Table 3. Number of farms that operated with nutrient mass balance (NMB) per hectare or per megagram of milk below and above the feasible ${ }^{1}$ benchmark in the initial (T1) and final (T2) periods of NMB assessment ${ }^{2,3}$

\begin{tabular}{|c|c|c|c|c|c|c|c|c|c|}
\hline \multirow{2}{*}{ Farm size } & \multirow{2}{*}{$\begin{array}{l}\text { Mass balance } \\
\text { compared with } \\
\text { benchmark }\end{array}$} & \multicolumn{2}{|c|}{ N1 balance } & \multicolumn{2}{|c|}{$\mathrm{N} 2$ balance } & \multicolumn{2}{|c|}{$\mathrm{P}$ balance } & \multicolumn{2}{|c|}{ K balance } \\
\hline & & Initial & Final & Initial & Final & Initial & Final & Initial & Final \\
\hline \multicolumn{10}{|l|}{ NMB (kg/ha) } \\
\hline \multirow[t]{2}{*}{ Small } & Below & 36 & 39 & 36 & 39 & 33 & 39 & 33 & 37 \\
\hline & Above & 6 & 3 & 6 & 3 & 9 & 3 & 9 & 5 \\
\hline \multirow[t]{2}{*}{ All } & Below & 41 & 45 & 41 & 45 & 38 & 48 & 36 & 43 \\
\hline & Above & 13 & 9 & 13 & 9 & 16 & 6 & 18 & 11 \\
\hline \multicolumn{10}{|l|}{ NMB ( $\mathrm{kg} / \mathrm{Mg}$ of milk) } \\
\hline \multirow[t]{2}{*}{ Small } & Below & 23 & 30 & 20 & 26 & 14 & 25 & 19 & 24 \\
\hline & Above & 19 & 12 & 22 & 16 & 28 & 17 & 23 & 18 \\
\hline \multirow{2}{*}{ Medium and large } & Below & 3 & 10 & 4 & 9 & 7 & 10 & 4 & 9 \\
\hline & Above & 9 & 2 & 8 & 3 & 5 & 2 & 8 & 3 \\
\hline
\end{tabular}

${ }^{1}$ For New York State, feasible NMB per hectare is defined as the lowest NMB that $75 \%$ of 102 dairy farms in New York State were able to achieve; feasible NMB per megagram of milk is defined as the lowest NMB that $50 \%$ of the 102 dairy farms were able to achieve (Cela et al., 2014).

${ }^{2} \mathrm{~T} 1$ represents the average nutrient mass balance for the first $2 \mathrm{yr}$ of data collection; T2 represent the average nutrient mass balance values for the final 2 yr of data collection.

${ }^{3} \mathrm{~N} 1$ represents $\mathrm{N}$ mass balance without considering $\mathrm{N}_{2}$ fixation, $\mathrm{N} 2$ represents an $\mathrm{N}$ balance that includes a yield-specific $\mathrm{N}_{2}$ fixation and assumes no manure is applied to legumes.

\section{Drivers of Change in NMB}

Change Over Time in Farm Size and Management Indicators. The farm size and management indicators showed only minimal changes over time when averaged across the 54 farms, but the range in change among farms was substantial (Table 1). Changes over time in NMB per hectare were negatively correlated with changes in the number of milk cows and tillable hectares $\left(\mathrm{R}^{2}=0.10\right.$ to $\left.0.19, P<0.05\right)$, changes in percentage of homegrown $\mathrm{N}$ and $\mathrm{P}$ fed $\left(\mathrm{R}^{2}=0.06\right.$ to 0.08 , $P<0.10$ ), and changes in $\mathrm{N}$ and $\mathrm{P}$ feed nutrient use efficiencies $\left(\mathrm{R}^{2}=0.08\right.$ to $\left.0.11, P<0.05\right)$; and positively correlated with changes in the animal density $\left(\mathrm{R}^{2}=\right.$ 0.10 for $\mathrm{N}$, and $\mathrm{R}^{2}=0.18$ for $\mathrm{P}, P<0.05$ ), milk production per hectare $\left(\mathrm{R}^{2}=0.07\right.$ to $\left.0.08, P<0.05\right)$, and concentration of $\mathrm{P}$ in the $\operatorname{diet}\left(\mathrm{R}^{2}=0.25, P<0.01\right)$ and in purchased feed $\left(\mathrm{R}^{2}=0.10, P<0.05\right)$. Changes over time in NMB per megagram of milk were positively correlated with changes in the percentage of land in legumes $\left(\mathrm{R}^{2}=0.07\right.$ to 0.10 for $\mathrm{N} 2$, and $\mathrm{R}^{2}=0.05$ for $\mathrm{K}, P<0.05)$, in the concentration of $\mathrm{P}$ in all feed $\left(\mathrm{R}^{2}\right.$ $=0.19, P<0.01)$, and in the purchased feed $\left(\mathrm{R}^{2}=\right.$ $0.13, P<0.01)$, and negatively correlated with changes in milk productivity per cow $\left(\mathrm{R}^{2}=0.05\right.$ to $0.07, P<$ 0.10 ), in the percentage of homegrown $\mathrm{N}, \mathrm{P}$, and $\mathrm{K}$ fed, and in feed $\mathrm{N}$ and $\mathrm{P}$ use efficiencies $\left(\mathrm{R}^{2}=0.15\right.$ for $\mathrm{N} 2$, and $\mathrm{R}^{2}=0.12$ for $\left.\mathrm{P}, P<0.01\right)$.
These results suggest that animal density, milk production per hectare, the percentages of homegrown feed and nutrients, nutrient concentrations in the feed, and nutrient feed use efficiency are key indicators that farmers should evaluate to identify potential areas of improvements in NMB per hectare, consistent with findings reported in other studies (Anderson and Magdoff, 2000; Erb and Fermanich, 2002; Spears et al., 2003a,b; Hristov et al., 2006). However, despite the significance of the relationships described above, the low coefficients of determination $\left(\mathrm{R}^{2} \leq 0.25\right)$ suggest that none of these indicators by themselves could predict the need and opportunity for change in management and associated decrease in NMB. This could be due to the fact that many changes can occur simultaneously. For example, an increase in the animal density may not result in higher NMB if the farm increases manure exports at the same time as well. Thus, it is important to evaluate changes over time for each of the individual import and export pools.

Change Over Time in Nutrient Imports and Exports. Change over time in total nutrient imports per hectare was a primary driver of change in NMB per hectare $\left(\mathrm{R}^{2}=0.78\right.$ to 0.85 , Figure $4 \mathrm{~A}$ to $\left.\mathrm{D}\right)$. In particular, purchased feed was the main driver of change in N1, $\mathrm{N} 2$ and $\mathrm{P}$ balances (Figures 1 and $4 \mathrm{E}$ to $\mathrm{H}$ ), whereas purchased fertilizer was the main driver of change in $\mathrm{K}$ balances (Figure 4I to L). On average across all farms, 

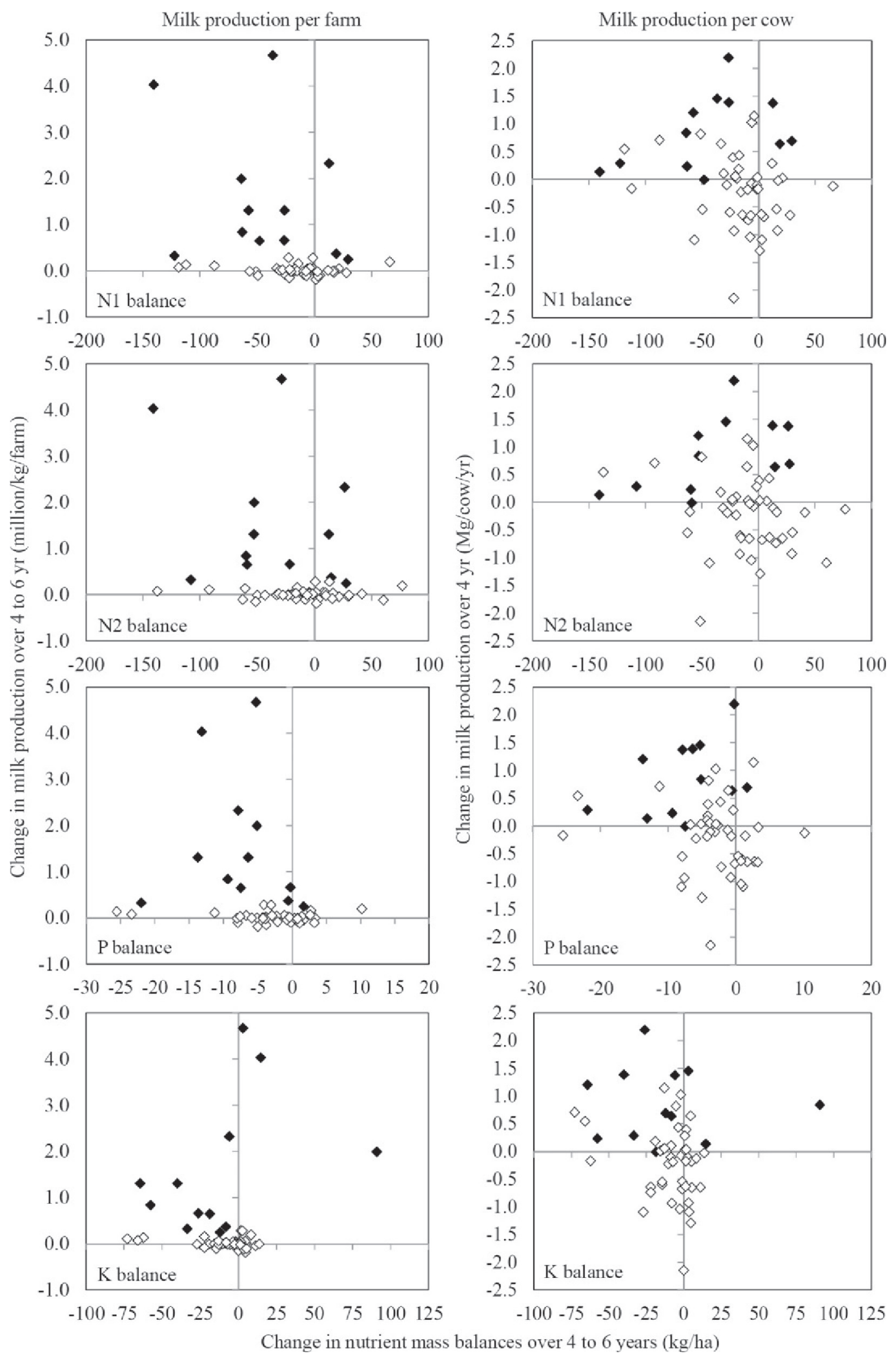

Figure 3. Change over 4 to 6 yr (T2 - T1) in milk production per farm (left column) and in milk production per cow (right column), as a function of the change over the same period in nutrient mass balances per hectare for nitrogen with $\mathrm{N}_{2}$ fixation (N1), nitrogen without $\mathrm{N}_{2}$ fixation (N2), phosphorus, and potassium for 54 dairy farms in New York State. Closed diamonds $(\bullet)$ represent medium and large farms (>200 cows), whereas open diamonds $(\diamond)$ represent small farms ( $<200$ cows $)$. 


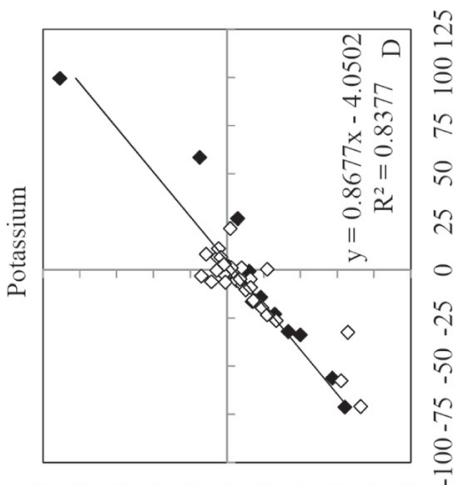

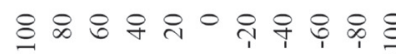

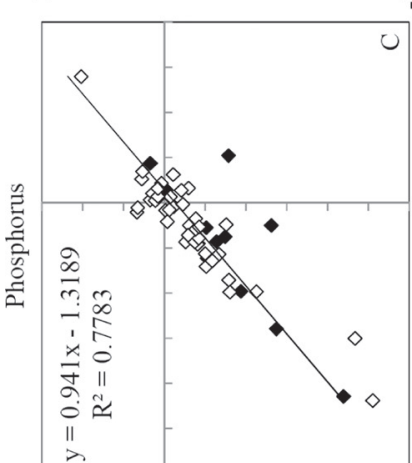

on o n o no no

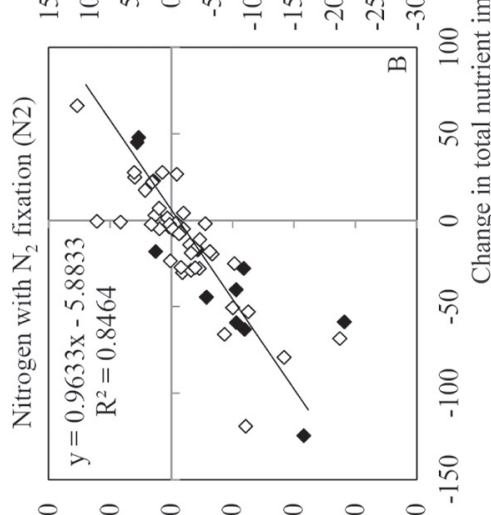

\& i 0 i 8 in

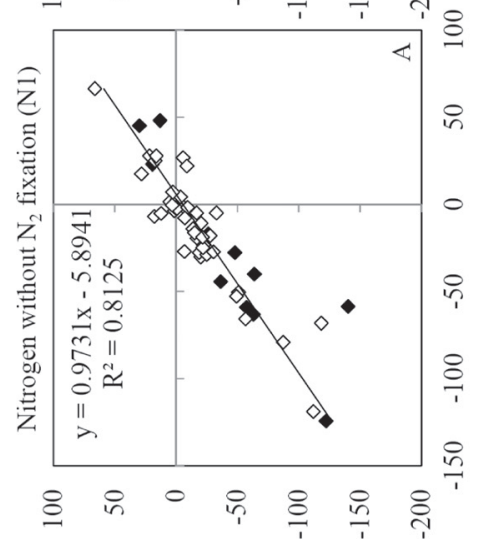

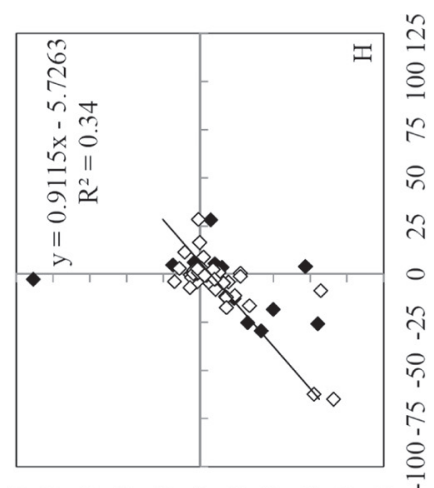

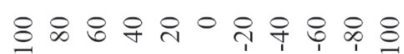
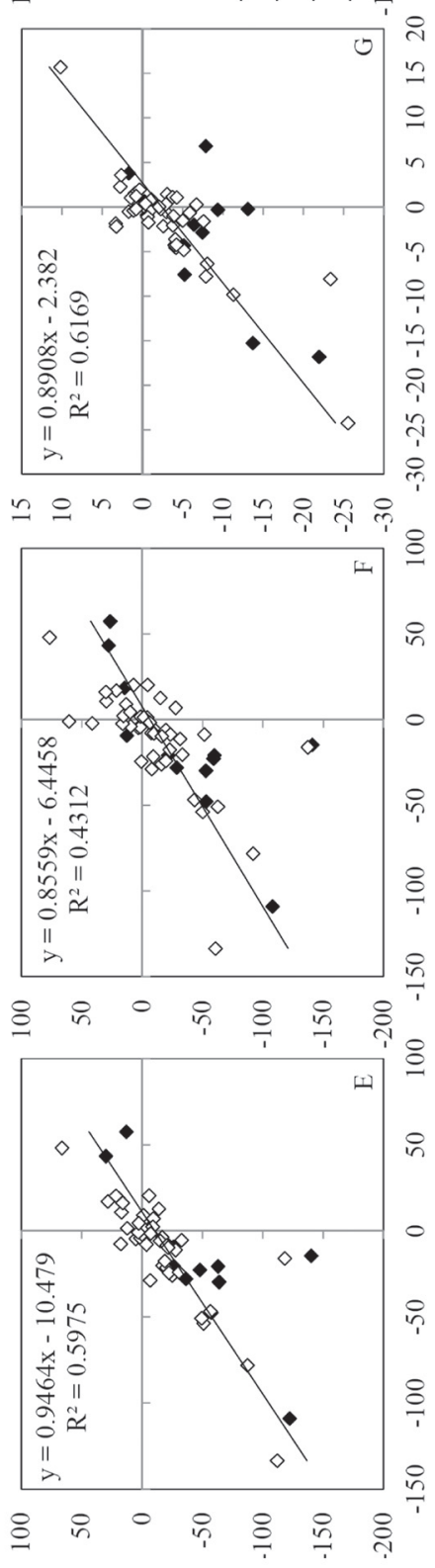

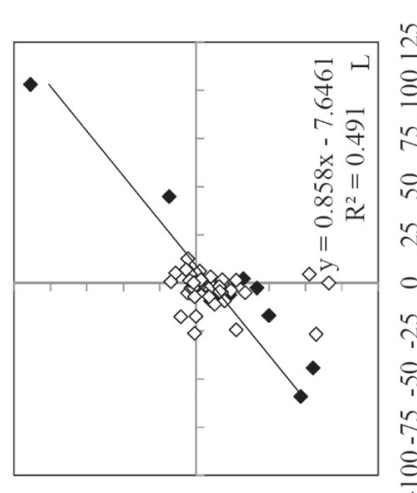

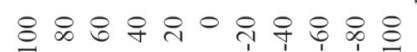

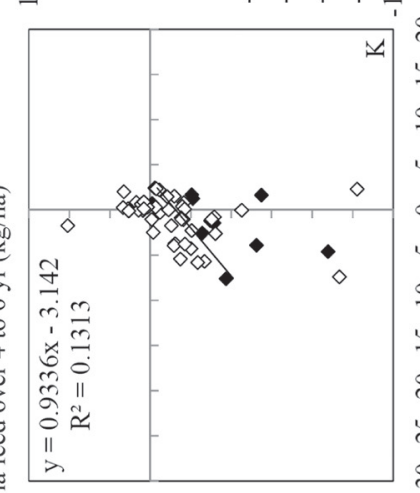

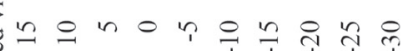
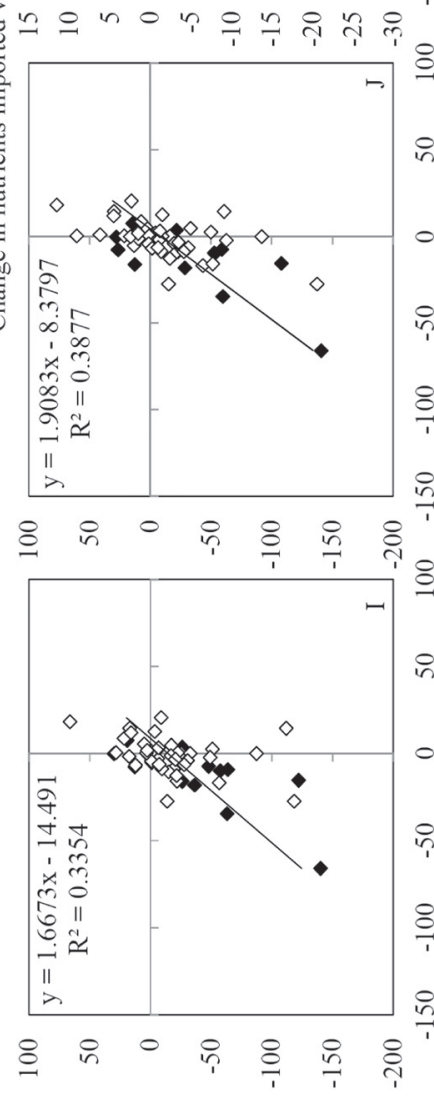

范 $\cdot \frac{\pi}{5}$

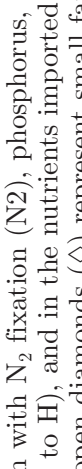

责国

둥

$\exists \underset{\square}{\infty}$

言它的

表范

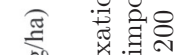

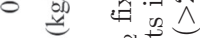

160 Z

品 +8

กे

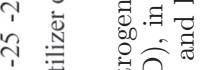

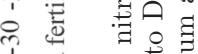

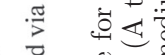

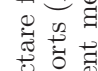

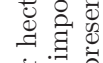

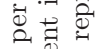

电

$\cong$ 胥

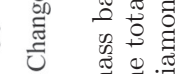

$8 \quad$ t.

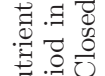

要过

政

称

1

$\mathrm{E}_{\mathrm{s}} . \exists$

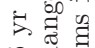

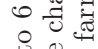

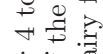

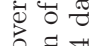

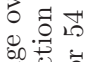

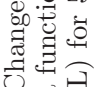

0

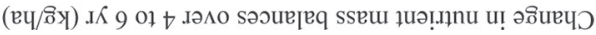

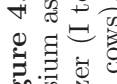


nutrients imported through feed decreased by $-12 \mathrm{~kg}$ of $\mathrm{N} / \mathrm{ha}$, by $-2 \mathrm{~kg}$ of $\mathrm{P} / \mathrm{ha}$, and by $-4 \mathrm{~kg}$ of $\mathrm{K} / \mathrm{ha}$ (Figures 1 and $4 \mathrm{E}$ to $\mathrm{H}$ ). On average, nutrients imported through fertilizer decreased by $-4 \mathrm{~kg}$ of $\mathrm{N} / \mathrm{ha}$, by -1 $\mathrm{kg}$ of $\mathrm{P} / \mathrm{ha}$, and by $-2 \mathrm{~kg}$ of $\mathrm{K} / \mathrm{ha}$ (Figures 1 and $4 \mathrm{I}$ to $\mathrm{L}$ ). Legume acres varied between the 2 time periods as well, increasing average $\mathrm{N}_{2}$ fixation by $5 \mathrm{~kg}$ of $\mathrm{N} / \mathrm{ha}$, and slightly affecting changes in the N2 balance across all farms $\left(\mathrm{R}^{2}=0.11, P<0.05\right)$. Changes over time in animal and miscellaneous imports were negligible $(<1$ $\mathrm{kg} / \mathrm{ha}$ ) for both farm sizes.

Changes in NMB per hectare were not closely correlated with changes in the total nutrient exports (Figure $5 \mathrm{~A}$ to $\mathrm{D}$ ), or in nutrients exported via milk (Figure $5 \mathrm{E}$ to $\mathrm{H}$ ), crops (Figure 5I to L), and manure NMB (Figure 5M to P). The most important changes in total $\mathrm{N}$ exports between $\mathrm{T} 1$ and $\mathrm{T} 2$ were evenly distributed among milk, crop, and manure exports (Figure 5). As some farms illustrated (Figure 5), also potential exists to reduce NMB over time by precisely managing fertilizers and by increasing crop exports (mainly in low-animal density farms) and manure exports (in high-animal density farms).

These results confirm that NY dairy farmers wanting to improve $\mathrm{N}$ and $\mathrm{P}$ balances per hectare should primarily focus on adjusting purchased feed (i.e., through precision feeding, as suggested by Kohn et al., 1997; Anderson and Magdoff, 2000; Powell et al., 2001; Spears et al., 2003b; Hristov et al., 2006), whereas adjustments in purchased feed and fertilizer should be mainly considered to improve $\mathrm{K}$ balances (as suggested by Erb and Fermanich, 2002).

In contrast to the findings for NY and other states in the United States, reported reductions in N surpluses over time in European dairy farms have been primarily driven by reductions in mineral $\mathrm{N}$ fertilizer purchases (Swensson, 2003; Nielsen and Kristensen, 2005; Groot et al., 2006; Nevens et al., 2006). In Sweden, reductions in $\mathrm{N}$ balances over time were primarily driven by reductions in the mineral $\mathrm{N}$ fertilizer use and in $\mathrm{N}_{2}$ fixation, without significant changes in $\mathrm{N}$ purchased through feed (Swensson, 2003). In Denmark, reduction in $\mathrm{N}$ balance per hectare over time in 8 conventional dairy farms reflected primarily a reduction in fertilizer use, but this reduction was counterbalanced by an increase in feed $\mathrm{N}$ imports over time (Nielsen and Kristensen, 2005). Not surprisingly, for 5 organic dairy farms in the Danish study, changes in $\mathrm{N}$ balances over time were primarily driven by reductions in feed purchases (Nielsen and Kristensen, 2005). In the Netherlands, reduced N fertilizer use on 45 commercial farms over 6 yr greatly affected NMB and on whole-farm $\mathrm{N}$ use efficiency (Groot et al., 2006). Nevens et al. (2006) reported that the reduction in $\mathrm{N}$ surplus in Flemish dairies $(-140$ $\mathrm{kg}$ of $\mathrm{N} /$ ha over $12 \mathrm{yr}$ ) was primarily driven by reductions in mineral fertilizer use $(-110 \mathrm{~kg}$ of $\mathrm{N} / \mathrm{ha})$ and by reductions in purchased concentrates $(-28 \mathrm{~kg}$ of $\mathrm{N} /$ ha), without changes in $\mathrm{N}$ export over time. Fertilizer represented a large proportion of the nutrient inputs in European dairies, which explains the emphasis on reducing fertilizer inputs.

It is not surprising that dairy farms in NY focused on feed management, because feed represents the significant majority of nutrient imports (Figure 1). For N, $\mathrm{P}$, and $\mathrm{K}$, change over time in feed imports were positively correlated with changes in animal density and negatively correlated with changes in farm-produced feed, and feed use efficiency (Table 4). Everything else remaining constant, (1) for every increase of $1 \mathrm{AU} / \mathrm{ha}$, associated increases in feed imports of about $66 \mathrm{~kg} \mathrm{~N} /$ ha, $10 \mathrm{~kg} \mathrm{P} / \mathrm{ha}$, and $18 \mathrm{~kg} \mathrm{~K} /$ ha were noted; (2) for every increase of $1 \%$ in the percentage of homegrown nutrients fed, associated decreases in feed imports of $-2.2 \mathrm{~kg}$ of $\mathrm{N} / \mathrm{ha},-0.3 \mathrm{~kg}$ of $\mathrm{P} / \mathrm{ha}$, and $-2.2 \mathrm{~kg}$ of $\mathrm{K} /$ ha were noted; and (3) for every $1 \%$ increase in nutrient feed use efficiency, associated decreases in feed imports of $-4.3 \mathrm{~kg}$ of $\mathrm{N} / \mathrm{ha},-0.5 \mathrm{~kg}$ of $\mathrm{P} / \mathrm{ha}$, and $-3.2 \mathrm{~kg}$ of $\mathrm{K} /$ ha were noted (Table 4 ).

Of the 54 farms, 63, 59, and $57 \%$ increased N, P, and $\mathrm{K}$ feed use efficiency over time. Considering the 54 farms, an improvement was observed over time in feed $\mathrm{N}$ and $\mathrm{P}$ use efficiency (average $=1 \%$, median $=2 \%$; Table 1); but the range of -18 to $9 \%$ for $\mathrm{N}$ and -17 to $17 \%$ for $\mathrm{P}$ was large, probably reflecting uncertainty in homegrown crop yields in some farms. The feed nutrient use efficiencies obtained in our study are lower than those reported in previous NMB studies in dairy farms [16 to $36 \%$ for N (Kohn et al., 1997; Powell et al., 2010), and 25 to $30 \%$ for P (Spears et al., 2003b; Nielsen and Kristensen, 2005)], probably because crop harvest losses and storage and feeding losses are included in the total feed assessment in our study.

Improvements in the feed nutrient use efficiency and NMB per megagram of milk are desirable because they reflect a reduction in nutrient losses while maintaining productivity (Kohn et al., 1997), whereas improvements in NMB per hectare are essential for addressing environmental effects (Nevens et al., 2006; Gourley et al., 2012). However, nutrient transfers among farms (feed, manure) only decrease global nutrient losses if the importing farms can use nutrients more efficiently than the exporting farm (Kohn et al., 1997), or if farms differ in transfer pathways that influence susceptibility to nutrient loss to the environment. This highlights the importance of reducing both NMB per unit of land and per unit of milk production to reduce the risk of 

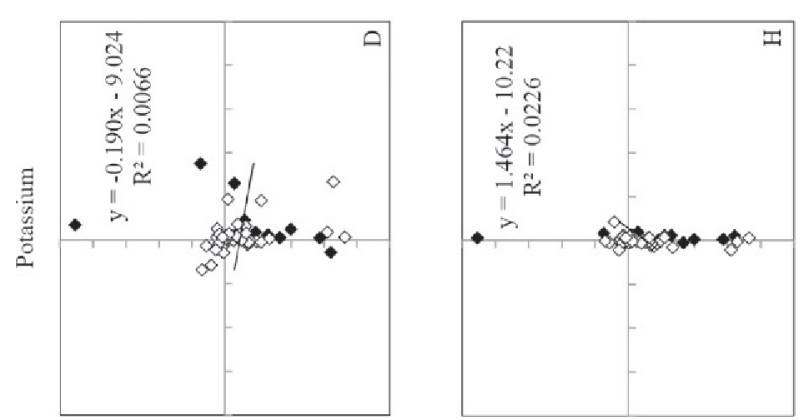

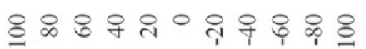

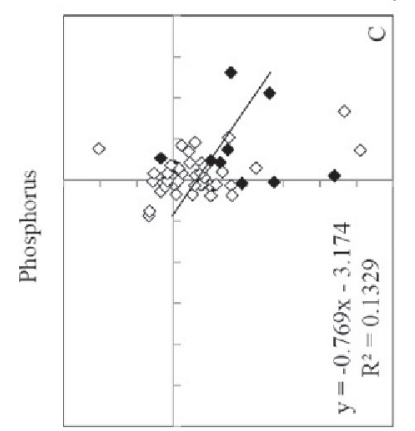

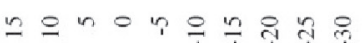
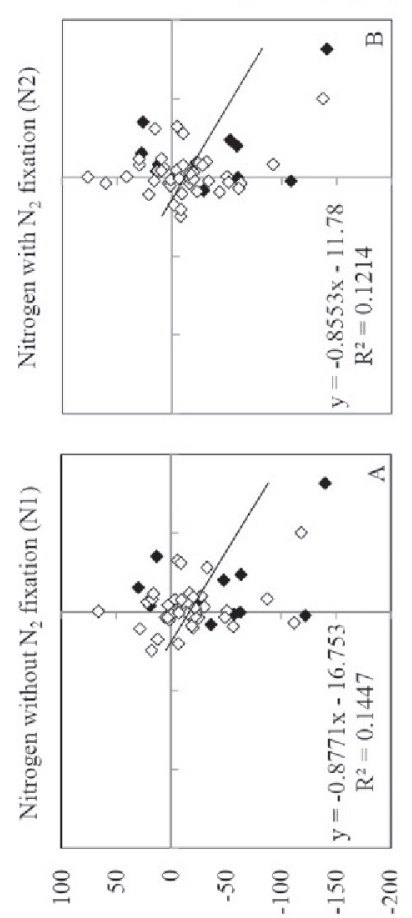
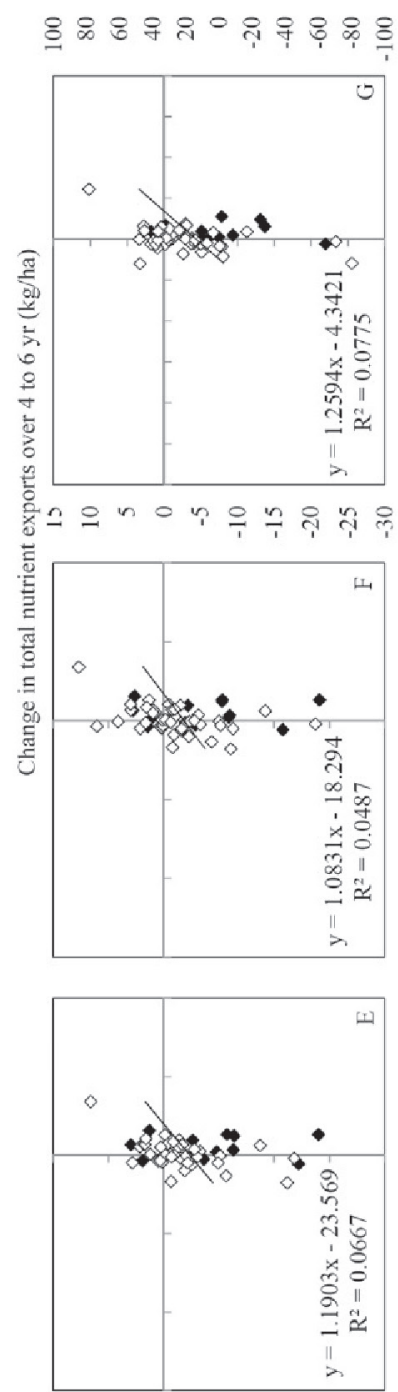

\&

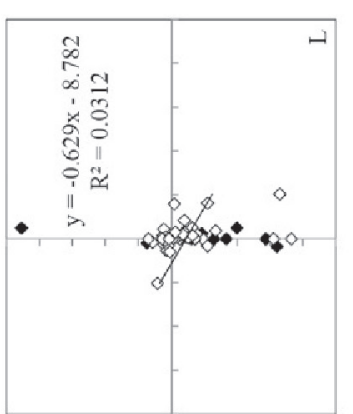

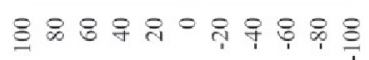
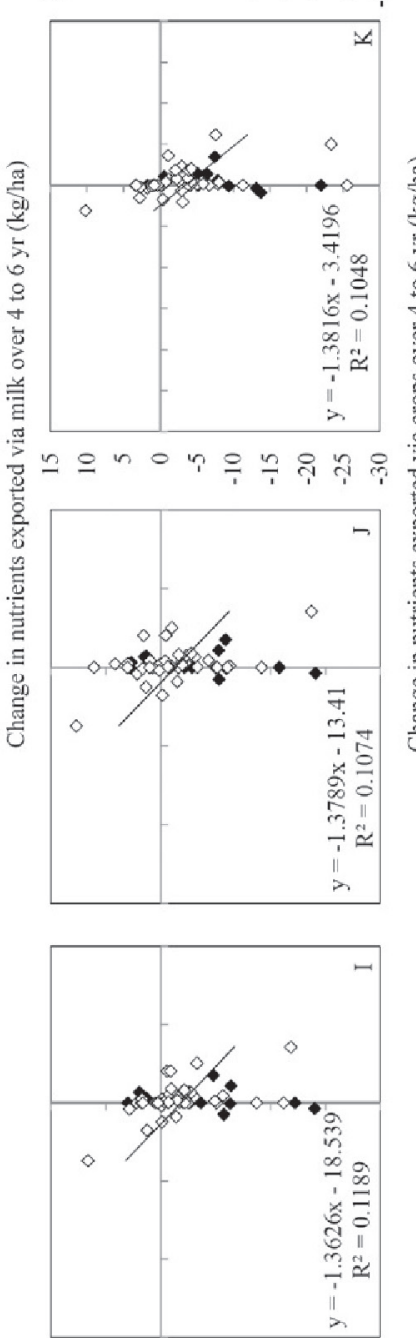

号 0 \%

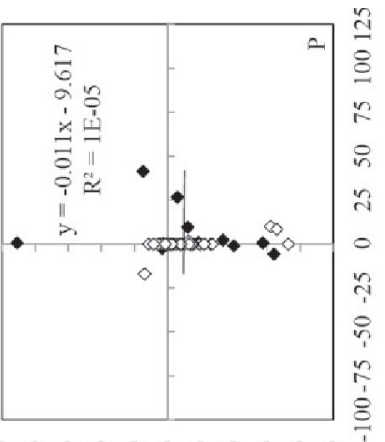

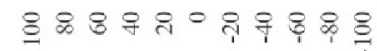
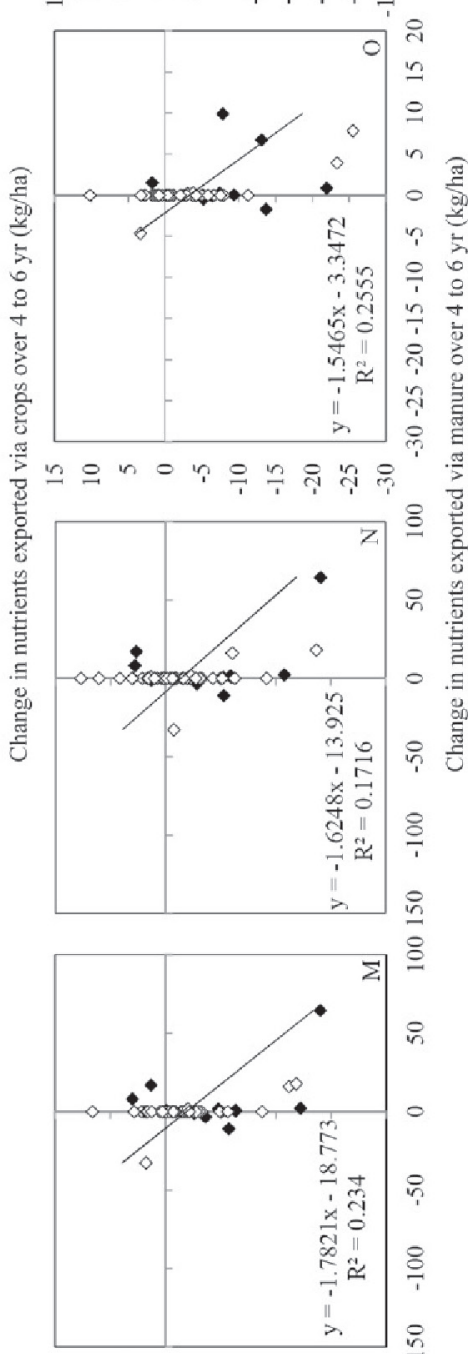

多

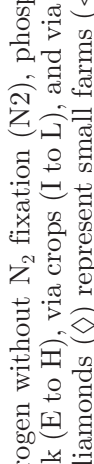

㐘家

둘

之芯要

要

造 :

设.

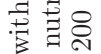

$\exists \unlhd$

이의

营宫

눙요용

$0 \varangle \frac{\pi}{4}$

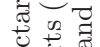

东

预

电.

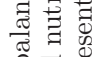

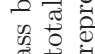

$\exists$

政

营.

욜.

$\exists$ :

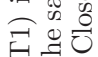

1 芯蓠

Evis

$5.0 \%$

0 응

$\rightarrow \frac{9}{4}$

离

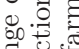

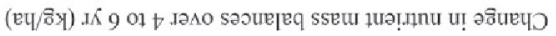

过

is

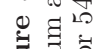

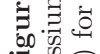


environmental pollution while maintaining productivity levels.

\section{Implications}

Our results highlight the importance of considering total imports, feed imports, animal density, farmproduced feed and nutrients, and feed nutrient use efficiencies as key indicators to identify potential areas for improvement in whole-farm NMB. For animal density, Cela et al. (2014) proposed a threshold of 2.4 $\mathrm{AU} /$ ha; farms that exceeded this threshold were highly likely to exceed the feasible benchmark NMB unless they exported manure or crops. The existence of similar thresholds could be explored for the other NMB efficiency indicators listed above to help farmers identify areas for improvement.

The annual NMB assessment allows farms to monitor their progress at the whole-farm level, providing a feedback mechanism that is central to the adaptive management approach introduced for use in agriculture and environmental management by NRCS (2013). Annual NMB can be used as an end-of-season report card, and a plan can be made to adjust management practices to improve NMB over time. This process can be essential in achieving effect over time, as illustrated by quotes from 3 participating farmers.

"Participating in the NMB validates that we're on the right track. In the first few years we couldn't be sure if the numbers were significant or just indicators of short term conditions. Over the years we can clearly see the trends are consistent. It's gratifying to see the drop in purchased feed while increasing milk production, and the moderation of soil phosphorus levels. The NMB data show that our practices are a win-win for the environment, herd health and farm economics."

"The NMB diagnostics have helped illustrate to farm management teams and environmental regulators that our farm's management changes are greatly reducing the amount of nutrients that could affect water resources. By tracking changes over time, a powerful message is delivered from the whole-farm perspective."

"At first I didn't find the NMB to be useful. Getting the data together was tough, because it didn't fit with my record keeping system. After about 2 yr I made some adjustments in tracking forage inventory, and that's helped both the NMB data needs and my feed system. I started tracking my baleage more specifically as to time of cutting and 
the field it came from. As yields have increased from the same number of acres, sales of baleage are taking nutrients off the farm as well as providing income. I now view hay quality as a nutrient efficiency issue as well as an economic one. The NMB also shows that I buy the same amount of feed as before the project, but I make more milk now from 74 cows than I did several years ago with 80."

\section{CONCLUSIONS}

The farms in our study improved their nutrient balance over 4 to $6 \mathrm{yr}$, with a considerably higher number of farms meeting the feasible NMB benchmarks for NY dairies in the most recent $2 \mathrm{yr}$ of assessment than during the first 2 yr of assessment. By utilizing an adaptive management approach that included completion of whole-farm NMB, 63 to $76 \%$ of farms reduced their NMB, becoming more nutrient efficient and reducing the potential for environmental effect. Moreover, 55 to $61 \%$ of farms that reduced their NMB per hectare over time were also able to increase milk production, becoming increasingly cost-efficient as well as nutrientefficient. Across all farms, the overall reduction in NMB per hectare over the 4 to $6 \mathrm{yr}$ averaged $-22 \mathrm{~kg}$ of N/ha for N1 (29\% reduction), $-16 \mathrm{~kg}$ of $\mathrm{N} /$ ha for $\mathrm{N} 2(15 \%$ reduction), $-4 \mathrm{~kg}$ of $\mathrm{P} / \mathrm{ha}$ ( $36 \%$ reduction), and -10 $\mathrm{kg}$ of $\mathrm{K} / \mathrm{ha}$ ( $29 \%$ reduction). Key nutrient use efficiency parameters in the NMB assessment that predicted the potential for improvement included the total amount of nutrient imports and purchased feed imports, animal density, farm-produced feed and nutrients, and feed nutrient use efficiency. We concluded that an adaptive management approach that includes annual whole-farm NMB and feasible targets can be effective in obtaining farm-level improvements in nutrient use over time while allowing for maximum flexibility with regard to selection of alternative practices for individual farms.

\section{ACKNOWLEDGMENTS}

We thank all the New York farmers, Soil and Water Conservation District, and Natural Resources Conservation Service staff, Cornell Cooperative Extension educators, and consultants who participated in this study. We are grateful to Francoise Vermeylen from the Cornell University Statistical Consulting Unit for statistical advice. This work was supported by grants from Northeast Sustainable Agriculture Research and Extension (NESARE), Northern New York Agricultural Development Program (NNYADP), Federal-Formula Funds, and USDA-NRCS.

\section{REFERENCES}

Anderson, B. H., and F. R. Magdoff. 2000. Dairy farm characteristics and managed flows of phosphorus. Am. J. Altern. Agric. 15:19-25.

Cela, S., Q. M. Ketterings, K. Czymmek, M. Soberon, and C. Rasmussen. 2014. Characterization of nitrogen, phosphorus, and potassium mass balances of dairy farms in New York State. J. Dairy Sci. 97:7614-7632. http://dx.doi.org/10.3168/jds.2014-8467.

Erb, K. A., and K. Fermanich. 2002. Nitrogen, phosphorus and potassium balances across dairy farm sizes: Do large dairies import more nutrients than small ones? University of Wisconsin Extension, Madison, WI. Accessed Oct. 28, 2014. http://soils.wisc.edu/ extension/wcmc/2002proceedings/Erb-Conf-2002.pdf.

Fangueiro, D., J. Pereira, J. Coutinho, N. Moreira, and H. Trindade. 2008. NPK farm-gate nutrient balances in dairy farms from Northwest Portugal. Eur. J. Agron. 28:625-634.

Gourley, C. J. P., W. J. Dougherty, D. M. Weaver, S. R. Aarons, I. M. Awty, D. M. Gibson, M. C. Hannah, A. P. Smith, and K. I. Peverill. 2012. Farm-scale nitrogen, phosphorus potassium and sulfur balances and use efficiencies on Australian dairy farms. Anim. Prod. Sci. 52:929-944.

Gourley, C. J. P., J. M. Powell, W. J. Dougherty, and D. M. Weaver. 2007. Nutrient budgeting as an approach to improving nutrient management on Australian dairy farms. Aust. J. Exp. Agric. 47:1064-1074.

Groot, J. C. J., W. A. H. Rossing, and E. A. Latinga. 2006. Evolution of farm management, nitrogen efficiency and economic performance on Dutch dairy farms reducing external inputs. Livest. Sci. 100:99-110.

Hristov, A. N., W. Hazen, and J. W. Ellsworth. 2006. Efficiency of use of imported nitrogen, phosphorus, and potassium and potential for reducing $\mathrm{P}$ imports on Idaho dairy farms. J. Dairy Sci. 89:3702-3712.

Ketterings, Q. M. 2013. Extension and knowledge transfer: Adaptive management approaches for timely impact. J. Agric. Sci. 152:5764. http://dx.doi.org/10.1017/S002185961300066X.

Kohn, R. A., Z. Dou, J. D. Ferguson, and R. C. Boston. 1997. A sensitivity analysis of nitrogen losses from dairy farms. J. Environ. Manage. 50:417-428.

Nevens, F., I. Verbruggen, D. Reheul, and G. Hofman. 2006. Farm gate nitrogen surpluses and nitrogen use efficiency of specialized dairy farms in Flanders: Evolution and future goals. Agric. Syst. 88:142-155.

New York Agricultural Statistics Service (NYSASS). 2012. New York Agricultural Statistics 2012. Annual Bulletin. USDA National Agricultural Statistics Service, New York Field Office, Albany, NY. Accessed Dec. 11, 2014. http://www.nass.usda.gov/ Statistics_by_State/New_York/Publications/Annual_Statistical_ Bulletin/2012/Annual\%20Bulletin\%202012.pdf.

New York Agricultural Statistics Service (NYSASS). 2014. New York Agricultural Statistics Years 2005 through 2011. Annual Bulletin. USDA National Agricultural Statistics Service, New York Field Office, Albany, NY. Accessed Dec. 11, 2014. http://www.nass. usda.gov/Statistics_by_State/New_York/Publications/Annual_ Statistical_Bulletin/.

Nielsen, A. H., and I. S. Kristensen. 2005. Nitrogen and phosphorus surpluses on Danish dairy and pig farms in relation to farm characteristics. Livest. Prod. Sci. 96:97-107.

NRCS (Natural Resources Conservation Service). 2013. Adaptive Nutrient Management Process. Agronomy Technical Note No. 7. NRCS, Washington, DC. Accessed Oct. 25, 2014. http://directives. sc.egov.usda.gov/OpenNonWebContent.aspx? content=33791.wba.

Oenema, O., and P. Berentsen. 2005. Manure policy and MINAS: Regulating nitrogen and phosphorus surpluses in agriculture of the Netherlands. Organisation for Economic Co-operation and Development, Paris, France. Accessed Oct. 24, 2014. http://search. oecd.org/officialdocuments/displaydocumentpdf/?cote $=\mathrm{COM} /$ $\mathrm{ENV} / \mathrm{EPOC} / \mathrm{CTPA} / \mathrm{CFA}(2004) 67 /$ FINAL\&docLanguage=En. 
Oenema, O., H. Kros, and W. de Vries. 2003. Approaches and uncertainties in nutrient budgets: Implications for nutrient management and environmental policies. Eur. J. Agron. 20:3-16.

Powell, J. M., C. J. P. Gourley, C. A. Rotz, and D. M. Weaver. 2010. Nitrogen use efficiency: A potential performance indicator and policy tool for dairy farms. Environ. Sci. Policy 13:217-228.

Powell, J. M., Z. Wu, and L. D. Satter. 2001. Dairy diet effects on phosphorus cycles of cropland. J. Soil Water Conserv. 56:22-26.

Rotz, C. A., F. Taube, M. P. Russelle, J. Oenema, M. A. Sanderson, and M. Wachendorf. 2005. Whole-farm perspectives on nutrient flow in grassland agriculture. Crop Sci. 45:2139-2159.

SAS Institute Inc. 2012. SAS/STAT User's Guide. Release 8.00. SAS Institute, Inc., Cary, North Carolina.

Soberon, M. A., Q. M. Ketterings, C. N. Rasmussen, and K. J. Czymmek. 2013. Whole farm nutrient balance calculator for New York dairy farms. Nat. Sci. Educ. 42:57-67.

Spears, R. A., R. A. Kohn, and A. J. Young. 2003b. Whole-farm nitrogen balance on western dairy farms. J. Dairy Sci. 86:4178-4186. http://dx.doi.org/10.3168/jds.S0022-0302(03)74033-8.

Spears, R. A., A. J. Young, and R. A. Kohn. 2003a. Whole-farm phosphorus balance on western dairy farms. J. Dairy Sci. 86:688-695. http://dx.doi.org/10.3168/jds.S0022-0302(03)73648-0.
Swensson, C. 2003. Analyses of mineral element balances between 1997 and 1999 from dairy farms in the south of Sweden. Eur. J. Agron. 20:63-69.

Swink, S. N., Q. M. Ketterings, L. E. Chase, K. J. Czymmek, and M. E. van Amburgh. 2011. Nitrogen balances for New York State: Implications for manure and fertilizer management. J. Soil Water Conserv. 66:1-17.

USDA-EPA (Environmental Protection Agency). 1999. Unified national strategy for animal feeding operations. USDA-EPA, Washington, D.C.

USDA-NASS (National Agricultural Statistics Service). 2009. 2007 Census of Agriculture. New York. State and County data. Volume 1. Geographic Area Series. Part 32. USDA-NASS, Washington, DC. Accessed Dec. 11, 2014. http://www.agcensus.usda.gov/ Publications/2007/Full_Report/Census_by_State/New_York/.

Wright, S., and C. Mallia. 2008. The Dutch approach to the implementation of the nitrate directive: Explaining the inevitability of its failure. J. Transdiscip. Environ. Stud. 7:1-5. 